\title{
'Nuovi' centri urbani: metodi e strumenti grafici per la lettura della qualità e della resilienza in luoghi extra moenia con caratteri storici consolidati
}

\author{
Giorgio Garzino \\ Maurizio Marco Bocconcino \\ Giada Mazzone \\ Mariapaola Vozzola
}

\section{Abstract}

Lo studio qui presentato è parte di una più ampia ricerca intrapresa da diverso tempo su nuovi temi del rilievo urbano, tesa alla definizione di un linguaggio fondato su una codifica di tipo grafico-simbolico capace di descrivere differenti ed eterogenei livelli conoscitivi di interesse per la città. Attraverso le possibili declinazioni del termine resilienza per i contesti urbani, la ricerca ripercorre, in una sorta di analisi ragionata, le premesse culturali e disciplinari del rilievo urbano per giungere, mediante affinamenti successivi, alla proposta di un sistema di rappresentazione. In questa occasione sono presentate alcune esplorazioni di carattere metodologico e applicativo, fondamento per approfondimenti successivi maggiormente sistematizzati. Si tratta qui di introdurre alcuni elementi di base da portare all'interno di un articolato sistema informativo per il rilievo della qualità, del benessere e della sicurezza come parametri ed elementi indicatori della resilienza urbana, anche con riguardo alle ricadute di impatto sociale, relativamente a nuovi centri per la città consolidata (tessuti storicizzati o oggetto di nuova progettazione). Oltre a quelli presentati in questa occasione, sono stati e saranno condotti ulteriori test circa il metodo proposto. Si tratta di un ambito di indagine che ormai è all'attenzione da alcuni anni e che si ritiene abbia raggiunto un risultato per tanta parte attendibile e stabilizzato, salvo alcune inevitabili messe a punto e maturazioni per le esperienze da condurre nei luoghi della città in trasformazione.

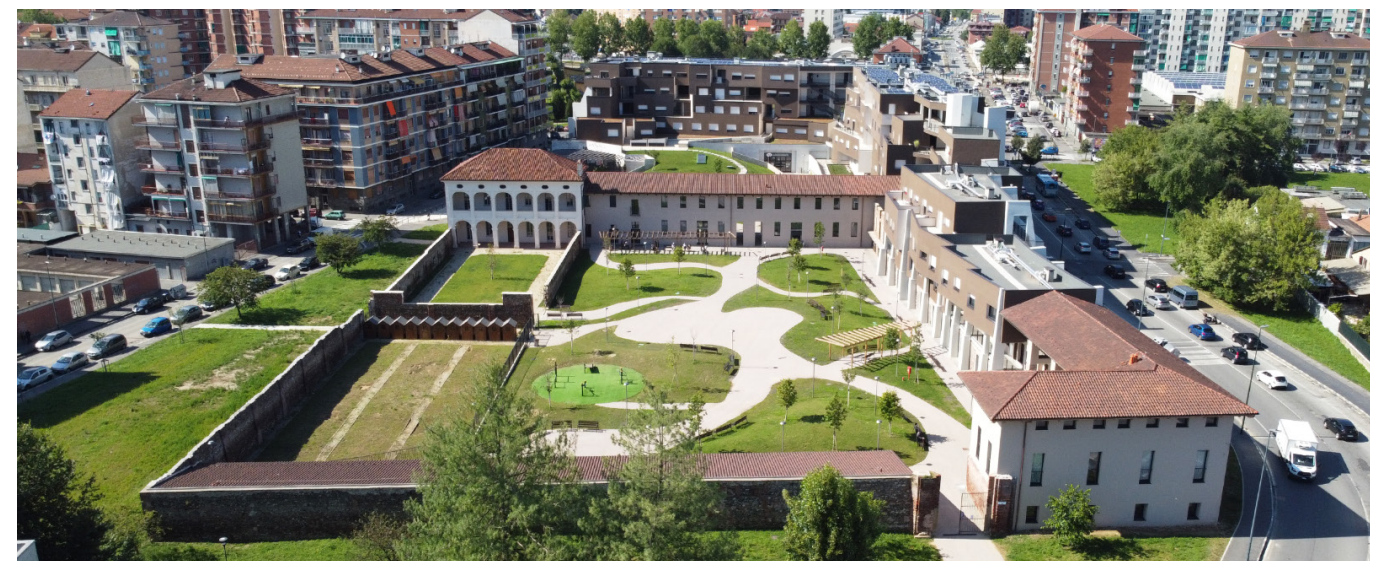




\section{Alcune considerazioni introduttive}

L'impianto della codifica di matrice cartografica e figurativa oggetto del presente contributo fa riferimento all'intero corpo delle ricerche compiute nell'arco degli ultimi cinquant'anni (riconducibili, seppure in termini attualizzati, per tanta parte sempre ai capisaldi costituiti da un lato agli studi di Kevin Lynch e dall'altro all'impostazione di Augusto Cavallari Murat) e prospetta metodi e linguaggi che, almeno nelle intenzioni, ne propongono un aggiornamento nel segno della continuità metodologica e scientifica.

La contemporaneità ci ha ormai abituati alla consuetudine di una comunicazione, qualsivoglia sia l'ambito a cui si riferisce, totalizzante, avvolgente e immediatamente diretta. È sembrato opportuno, quindi, mettere in campo modelli di rappresentazione capaci di radunare e raccogliere criticamente le conoscenze acquisite proponendone una lettura articolata su diversi livelli di analisi e di rappresentazione.

II rilievo della qualità e del benessere urbani è articolato in ragione delle finalità, differenti quindi gli esiti attesi. Lo sviluppo della ricerca ha tra gli obiettivi quello di 'mettere a sistema' le diverse componenti (rilevatori, studiosi, progettisti, strumenti, dati e patrimonio informativo), sfruttando il valore di efficienza che può derivare dalla formalizzazione informatica degli aspetti collegati al supporto dell'analisi e al relativo risultato grafico-numerico. Di questa tappa di approfondimento degli aspetti operativi di campo, occorre evidenziare il carattere di trasparenza, diffusione e partecipazione come aspetto discriminante per la buona riuscita dei processi di trasformazione e riuso degli spazi urbani. I disegni e le illustrazioni proposti ci auguriamo diventino un campo di confronto all'interno del quale sarà possibile attivare raffronti e dibattiti; per natura stessa della rappresentazione grafica essa infatti riesce a mettere in luce, attraverso un insieme ordinato di elementi e procedure, differenti punti di vista con appropriati linguaggi grafici. (M.M.B., G.G.).

\section{Cartografia storica per la descrizione della città contemporanea}

La ricerca intende avvalorare come i criteri di qualità dell'architettura, oggi alla base dei progetti di rigenerazione urbana finalizzati ad accrescere la resilienza dei luoghi, debbano poggiare innanzitutto sullo studio delle condizioni geografiche, territoriali e urbane dei luoghi.

L'ambito di interesse di questo studio non riguarda soltanto le caratteristiche insediative ed il rapporto tra architettura e luogo, ma riguarda la costruzione stessa dell'architettura e la sua trasformazione nel tempo, la cui natura e qualità non può prescindere da essi.

La questione centrale attorno alla quale questa ricerca prende le prime mosse, si articola sul ruolo conoscitivo che la rappresentazione ha nei confronti dell'architettura e del disegno urbano e sulle possibili operatività che offre come strumento capace di costruire ed elaborare un patrimonio culturale, conoscitivo e d'indirizzo propri di chi governa le trasformazioni delle città e del territorio.

L'importanza del lavoro di conoscenza e di analisi nei processi di evoluzione urbana si manifesta a partire dalla nascita dell'urbanistica moderna', come emerge dalle parole di Giuseppe Samonà in L'urbanistica e l'awenire della città: "Ė interessante rilevare che le osservazioni delle città in continuo rivolgimento e sviluppo, pur essendo di carattere particolare costituiscono il nucleo originario di osservazione sempre più estese sui fenomeni urbani, che per la prima volta insegnano a vedere la città al di dentro, nelle molteplici manifestazioni della sua attività, creando così il primo contesto di una disciplina urbanistica gradatamente più consapevole dei suoi compiti e delle sue funzioni"' [Samonà 1967, p. 7].

Questo ha contribuito sempre di più ad immaginare la necessità di ordinare con metodo, distinguere e collegare, in rapporto al carattere urbano, le varie parti della città ovvero di ricercare tecniche di rappresentazione in grado di rendere visibile ciò che può non essere tale. Nella complessità fisica del territorio contemporaneo questo modo di indagare i fenomeni urbani, che prevede la costruzione di tecniche per il riconoscimento delle 'molteplici manifestazioni' delle attività della città e delle sue parti, ha condotto a studi che indagano il ruolo giocato dalla rappresentazione dell'architettura e della città (dispositivi convenzionali e rap- 
Fig. I. Cascina La Fossata nella struttura geografica e urbana di Torino.
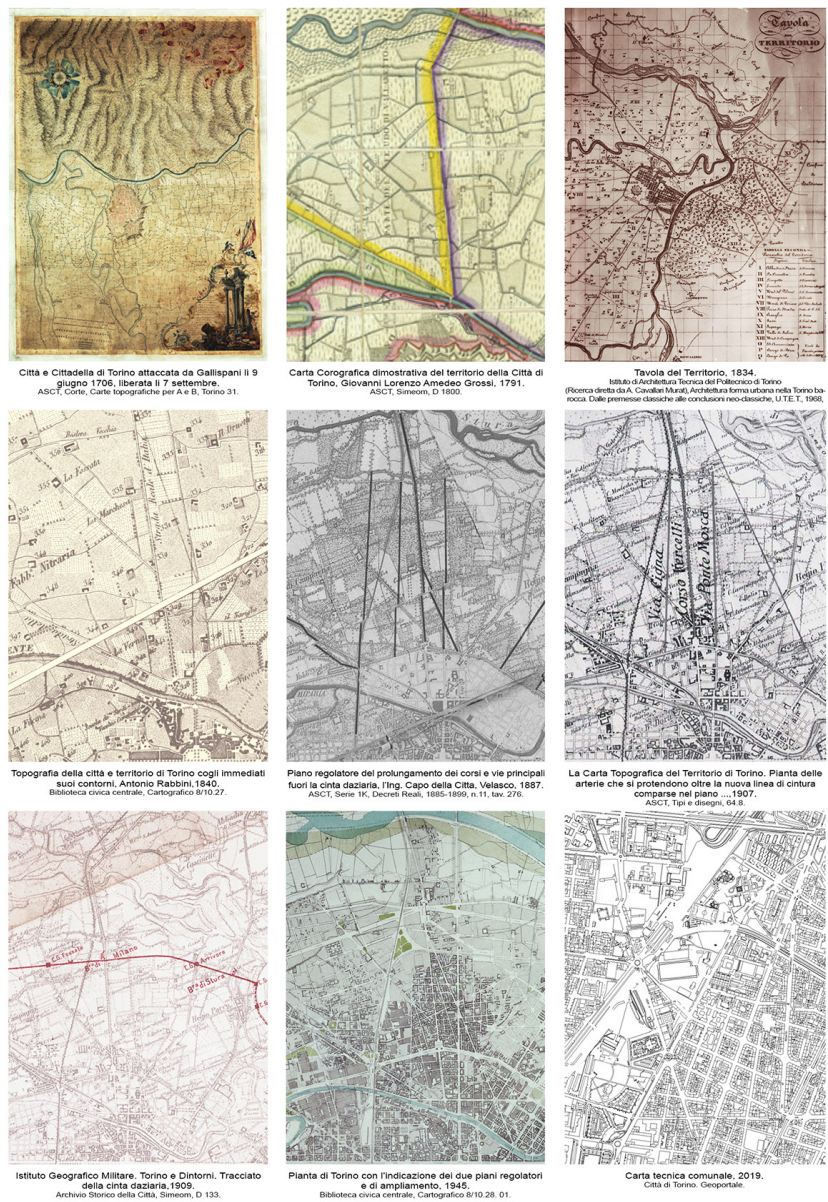

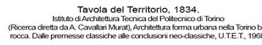
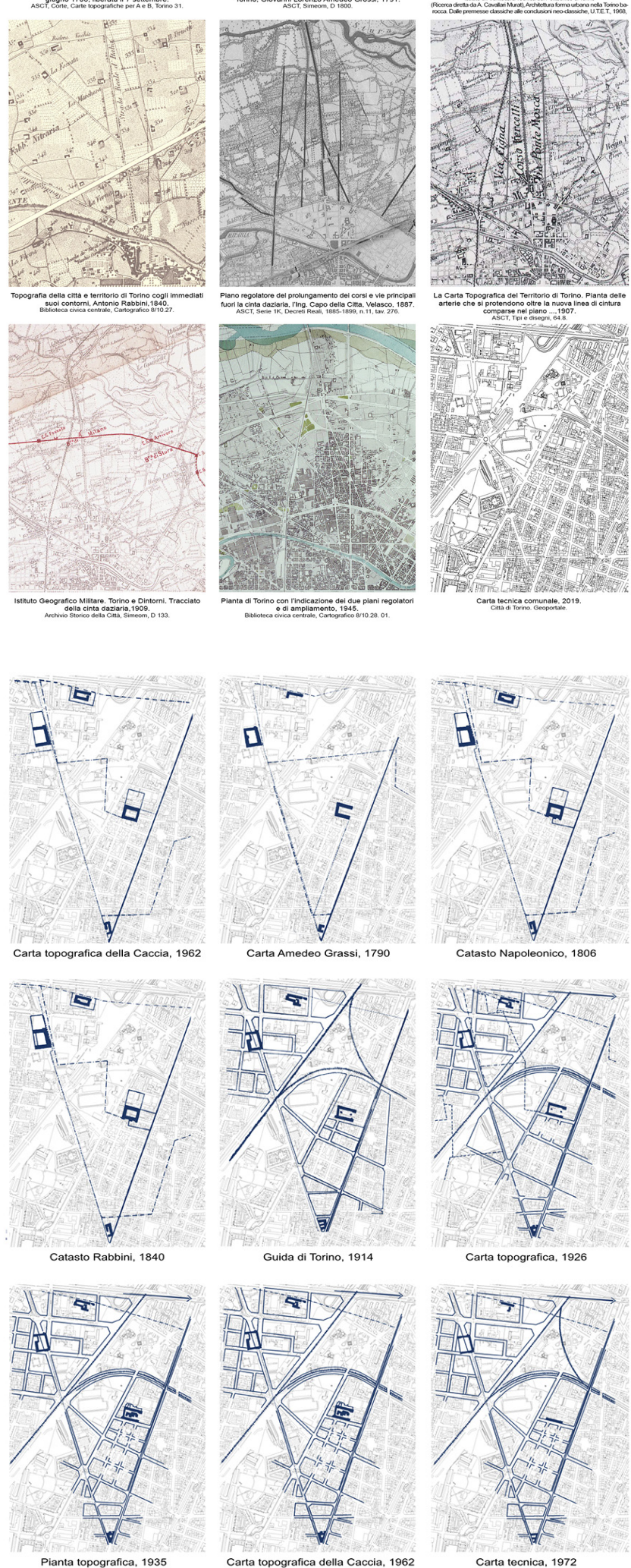
Fig. 3. In ordine: Carta della Montagna 1694-1703. Archivio Storico della Citta di Torino, Pianta dei terreni di Madonna di Campagna 1683. Archivio Storico della Città di Torino, Carta Tipografica della Campagna 1685. Archivio Storico della Città di Torino, Disegno dei confin territoriali 1785. Archivio Storico della Città di Torino, Carta Corografica dimostrativa del territorio Amedeo Grossi |791. Archivio Storico dell Archivio Storico della Città di Torino, Catasto Napoleonico 1805. ArChivio di Stato di Torino, Catasto Gatti 1820-1830. Archivio Storico della Città di Torino, Carta Antonio Rabbini 1840, Catasto Rabbini 1866 Archivio di Stato di Torino, Pianta di Torino 1935. Archivio Storico della Città di Torino, Carta dell'Istituto Geografico Militare 1974. Archivio Storico della Città di Torino. presentazione diagrammatica), del territorio (cartografia tematica), e degli aspetti sociali e economici (segni e simboli) nella descrizione dei luoghi.

La città e il suo territorio sono oggi sempre di più un punto di riflessione e di indagine privilegiato sui temi nodali che percorrono il nostro tempo e si impongono alla nostra attenzione con la necessità di 'metabolizzare' il passato perché diventi 'produttivo per il presente'. In urbanistica, e in architettura, la resilienza è connessa a "un'idea particolare d'intelligenza capace di rimodellarsi rispetto alla complessità degli eventi che stanno destrutturando le città" [Infante 2014, p. 49]. Gli studi di storia urbana, le monografie di città, le indagini archeologiche su ciò che resta delle città antiche, gli atlanti che raccolgono le immagini delle città nel tempo, le descrizioni dei diversi tipi di formazioni urbane e degli insediamenti presenti in una regione risalenti a particolari momenti della storia, che sono stati prodotti con accentuata intensità a partire dal XIX secolo, possono permetterci di rintracciare gli eventi del passato e possono essere strumento per rappresentare le tracce tangibili dei luoghi rievocando la loro identità (figg. I-4).

Su quelle elaborazioni grafiche e cartografiche possiamo fondare le successive conoscenze dei caratteri formali delle città e dei territori e da quelle rappresentazioni possiamo avviare sperimentazioni di nuovi modi di rappresentazione e far convergere i caratteri della qualità urbana e i diversi risultati dei diversi ambiti disciplinari. Sono rappresentazioni di un territorio che possono essere condivise perché nello spazio cartografico possono convivere infiniti strati. Le carte hanno la capacità di rappresentare differenti sguardi, espressioni di diversi interessi e identità offrendo così attraverso segni e simboli convenzionali la possibilità di progettare la compresenza stratificata delle molteplici categorie che costituiscono i territori contemporanei (fig. 5).
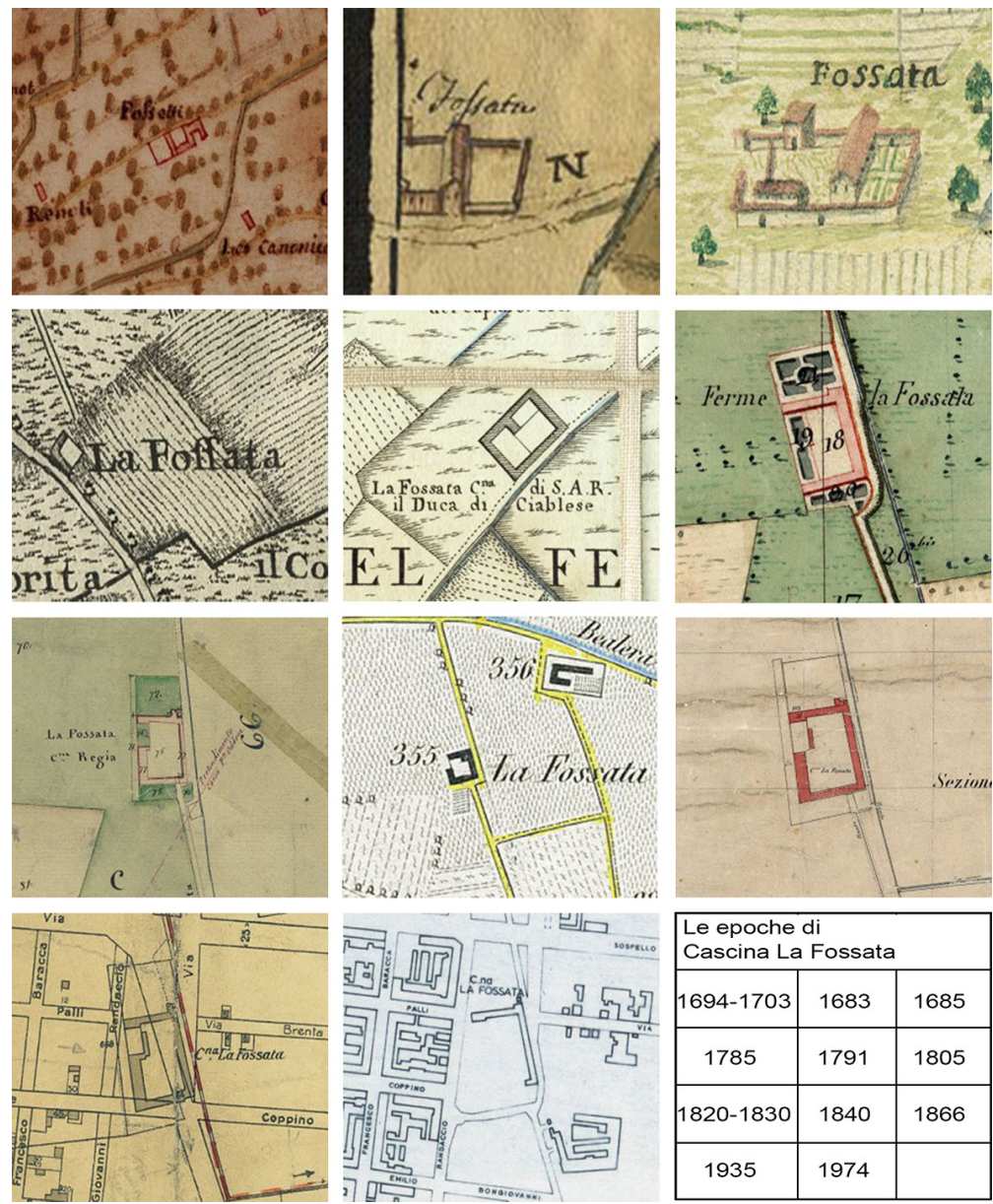

\begin{tabular}{|c|c|c|}
\hline \multicolumn{3}{|c|}{$\begin{array}{l}\text { Le epoche di } \\
\text { Cascina La Fossata }\end{array}$} \\
\hline 1694-1703 & 1683 & 1685 \\
\hline 1785 & 1791 & 1805 \\
\hline $1820-1830$ & 1840 & 1866 \\
\hline 1935 & 1974 & \\
\hline
\end{tabular}


Fig. 4. Pianta dei piani terra. Schema funzionale della Cascina La Fossata. Rilievo filologico congetturale della Cascina La Fossata [Istituto di Architettura Tecnica del Politecnico diTorino 1968 Vol. I, II; B. fig. 27].
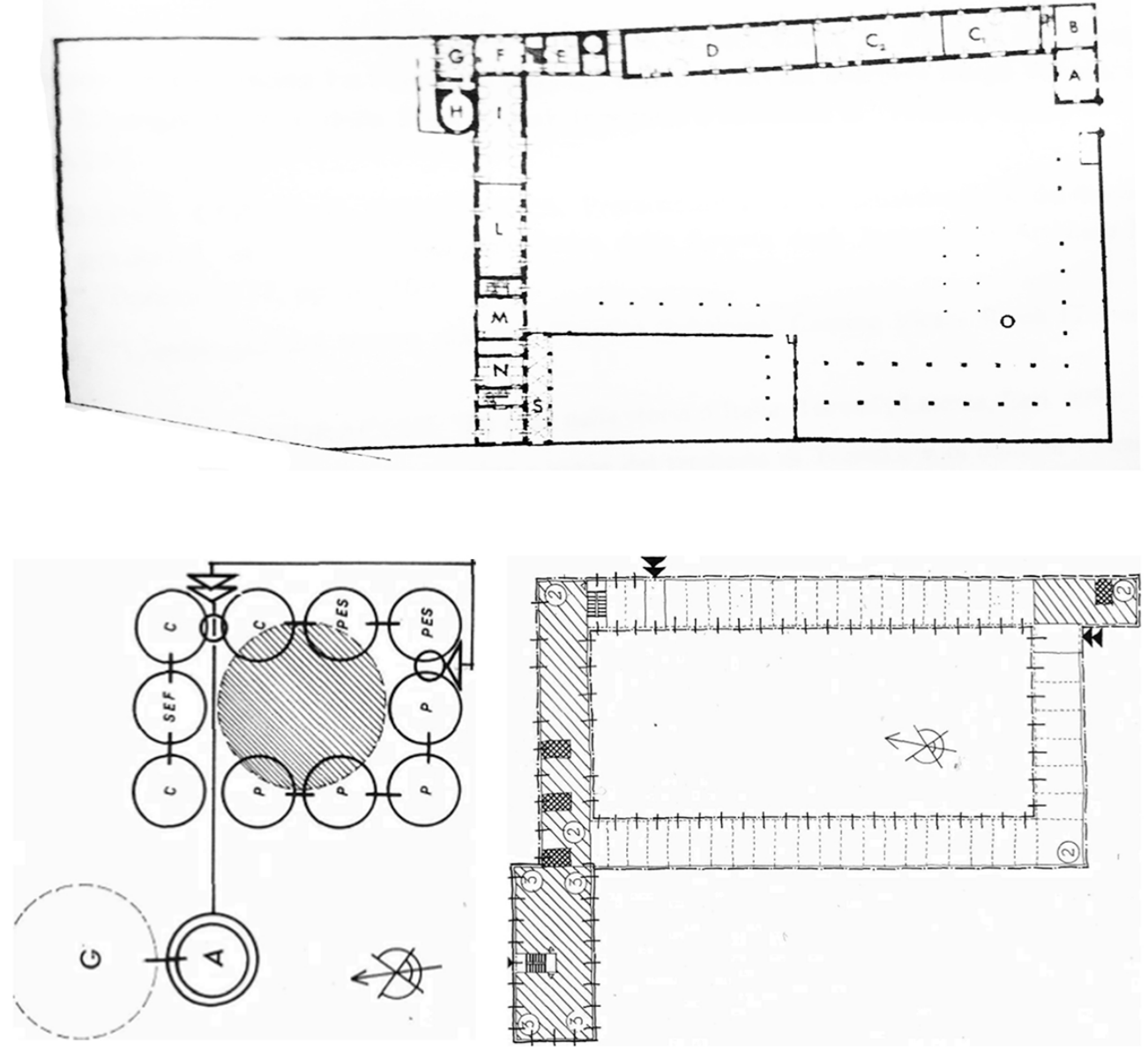

La rappresentazione può in questa accezione "tracciare infinite storie che si dissimulano nelle parole, che generano figure, che hanno insondabili profondità semantiche, possono assumere le sembianze di un filo che annoda e tesse le relazioni" (UID 2020) fra antichi, nuovi e rinnovati saperi sulla città.

Lavorare per descrivere ciò che resta delle esperienze passate non vuol dire necessariamente ricostruire, nella complessità della città contemporanea, attraverso le tracce e i segni, un'immagine spesso ormai irrimediabilmente perduta, ma cercare una 'riconnessione' dei diversi frammenti. La rappresentazione di questi frammenti può, nella costruzione di una sottile ragnatela di relazioni, lavorare sia sul piano fisico che sulla risignificazione e ri-generazione di uno spazio urbano.

L'approfondimento sviluppato in questo momento della ricerca riguarda il caso dell'insediamento di Cascina La Fossata a Torino, di origine seicentesca, edificata a nord del centro storico di Torino nel territorio agricolo allora definito 'campagna di Torino'. Attualmente inglobata nel tessuto urbano a seguito di un lungo periodo di abbandono è oggetto di un recente intervento di rigenerazione. II caso della cascina presenta alcune caratteristiche significative per discutere e sperimentare strumenti di rappresentazione per la valutazione dei requisiti di qualità urbana: il rapporto che essa ha intrattenuto e tuttora intrattiene con i caratteri geografici del luogo, la relazione che ha con la logica della struttura insediativa della città di Torino, le trasformazioni architettoniche subite nel corso della storia e il recente intervento di ri-generazione rappresentano il fondamento delle considerazioni del successivo paragrafo. (G.M.). 
Fig. 5. Cascina La Fossata nel territorio torinese, elaborazione su Carta Topografica di A. Rabbin 1840. (Antonio Rabbini, Topografia della città e Territorio di Torino. Archivio Storico della Città di Torino)

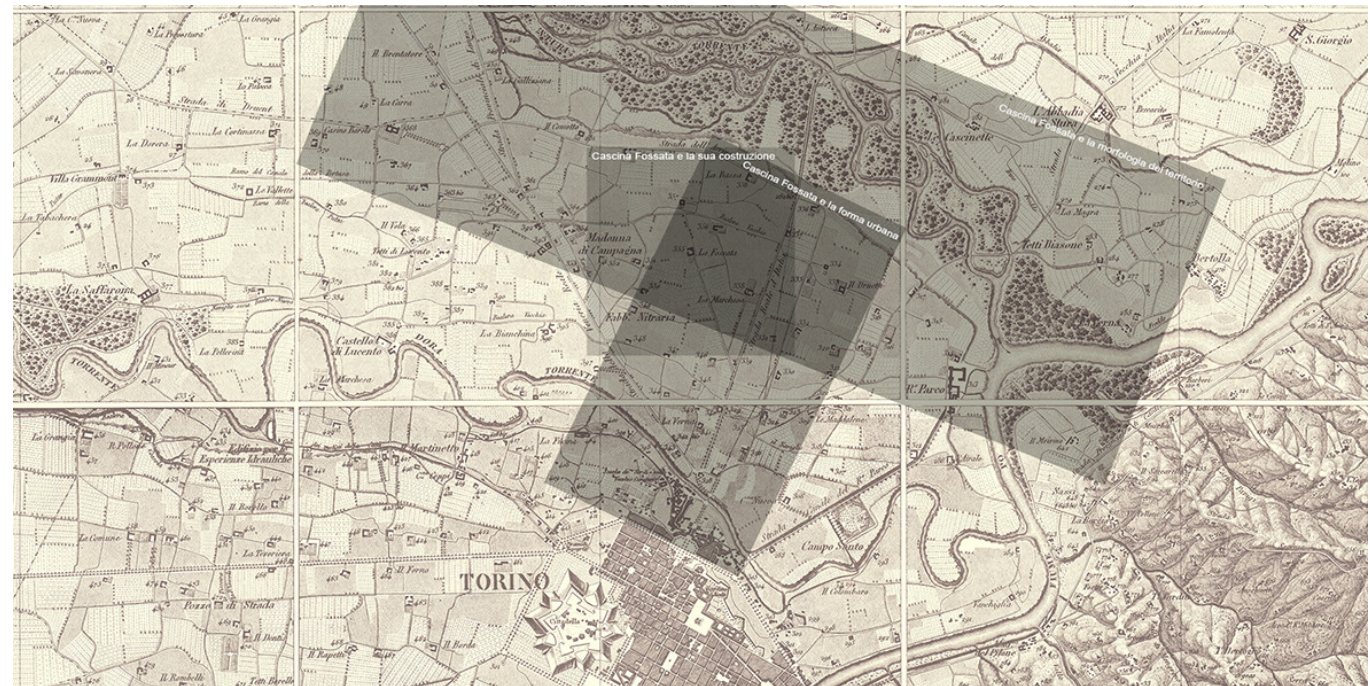

\section{II rilievo e la rappresentazione degli spazi urbani e della loro qualità}

La rappresentazione a scala urbana delle aree individuate come caso studio è intesa come uno strumento di analisi conoscitiva legata non solo all'indagine e al rilievo del singolo manufatto architettonico, ma come osservazione e studio allargato ad un contesto urbano specifico e caratterizzante, quale tessuto tipico della prima periferia di Torino. La ricerca è volta all'analisi di parametri ed indicatori rappresentativi dell'evoluzione socioculturale delle aree di interesse, al fine di dare evidenza dei cambiamenti della morfologia e dell'identità del luogo a seguito di interventi di 'riqualificazione' e di implementazione dei servizi territoriali, e di valutare, in una seconda fase, eventuali interventi migliorativi. La metodologia di rilievo, di analisi e di rappresentazione che verranno utilizzate nelle diverse fasi di ricerca, trae spunto da metodi di analisi in parte dedotti da casi già sviluppati in letteratura, ma tuttavia calati e ridefiniti nei loro perimetri di intervento e di utilizzo, e allo stesso tempo resi in parte innovativi con l'introduzione di nuovi codici di rappresentazione, al fine di poter rispondere alle esigenze dei particolari temi di studio. Tutti i dati, raccolti e rappresentati a seconda delle necessità con modalità diverse, convoglieranno all'interno di un modello multi scala e multi contenuto facilmente leggibile e interrogabile: in questo modo lo spazio urbano, sarà indagato non solo come elemento architettonico e geometrico, ma anche e soprattutto studiato valorizzando parametri 'immisurabili', 'immateriali' ed 'impalpabili' che ne caratterizzano il comportamento urbano, e ponendo l'attenzione sul singolo individuo che lo vive e sulla comunità in cui è inserito. L'obiettivo è quello di ottenere un insieme di rappresentazioni, esaustivo nella sua completezza di scala, in grado di armonizzare ed amalgamare al suo interno i diversi livelli di lettura, ma soprattutto, in grado di collegare dati ricavati da strumenti volti all'analisi 'analitica' del contesto urbano e architettonico, e dati ottenuti da strumenti di analisi 'percettivi', che con accorgimenti ad hoc, possano trasformare il dato percettivo soggettivo in analitico, al fine di poter utilizzare tali parametri per confrontare situazioni precedenti l'intervento con situazioni successive allo stesso (fig. 6).

Dai rilievi e dalle analisi svolte all'interno dell'area di studio, sono emerse, in prima battuta, quattro dimensioni di ambiti di studio, ai quali saranno associati ambiti di rappresentazione diversi:

I. Visivo_percettiva | che comprende le valutazioni di densità spaziale percepita, sia in senso urbanistico-architettonico, che in ambito umano-sociale;

2. Della fruizione | inerente alla valutazione della disponibilità delle strutture funzionali (ad esempio edifici commerciali, scuole, ospedali, centri sportivi, ...);

3. Socio relazione | che pone l'accento sulla popolazione e sulle relazioni sociali;

4. Contesto | che analizza tutti gli aspetti relativi al contesto urbano e ambientale in cui è inserito l'ambito di studio. 
Fig. 6. Ambiti di studio dei criteri e gli indici di valutazione (elabor
a cura dell'autore).

Fig. 7. Esempio di sequenza di studio: dall'esterno verso l'interno della

prima corte di Cascin Fossata (elaborazione a cura dell'autore).
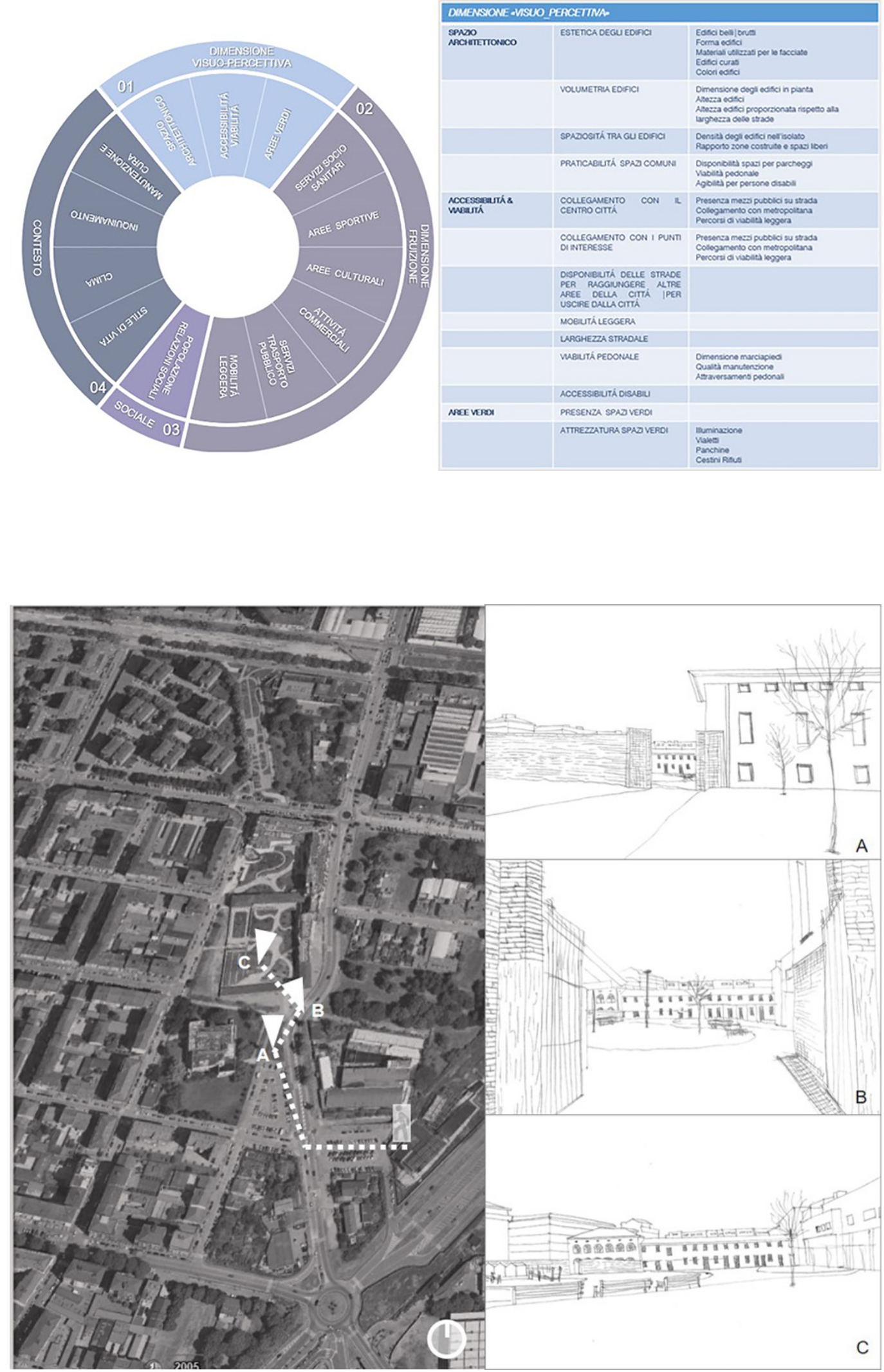
La rappresentazione e la definizione/descrizione della forma urbis, delle risorse ambientali, storiche, territoriali e l'analisi delle loro relazioni, ma soprattutto le molteplici informazioni e dati legate all'ambito di indagine, fin dalle prime fasi, avverranno non solo attraverso la definizione degli indici, ma anche attraverso la realizzazione di immagini e di quadri sequenziali, che analizzano i diversi livelli che definiscono l'ambiente nella sua totalità (fig. 7).

Le immagini si presentano come sintesi figurative dei momenti e processi conoscitivi condotti non solo su componenti formali e strutturali e sulla storia dei contesti urbani e di architetture, ma anche su forme e modalità di vita della società che ne ha legittimato o ne legittima l'esistenza. Le immagini della città costruita si concretizzano in prima battuta in disegni e schizzi, per fissare pensieri ed emozioni al cospetto di un ambiente urbano, e in fasi successive discretizzate e raccontate all'interno di schede di analisi qualitative e quantitative, cartografie tematiche, rappresentazioni bidimensionali e tridimensionali e brevi filmati.

L'oggetto di indagine è rappresentato e interpretato mediante percorsi di avvicinamento: l'utilizzo delle sequenze ha enfatizzato il ruolo dei livelli e le proiezioni in diverse versioni, per questo motivo sono state riprodotte più immagini - fotografiche e grafiche - che descrivono lo stesso quadro urbano ponendo l'attenzione sui componenti che costituiscono la scena, valutandone l'incidenza della singola categoria all'interno dell'insieme. I temi di classificazione impiegati sono stati in una prima fase quelli della valutazione tra ambiente privato e ambiente pubblico e in una seconda fase quelli della dimensione Visivo-percettiva comprendente le valutazioni di densità spaziale percepita, sia in senso urbanistico-architettonico, che in ambito umano-sociale, ponendo l'accento sugli aspetti Architettonici - Urbanistici. Sono
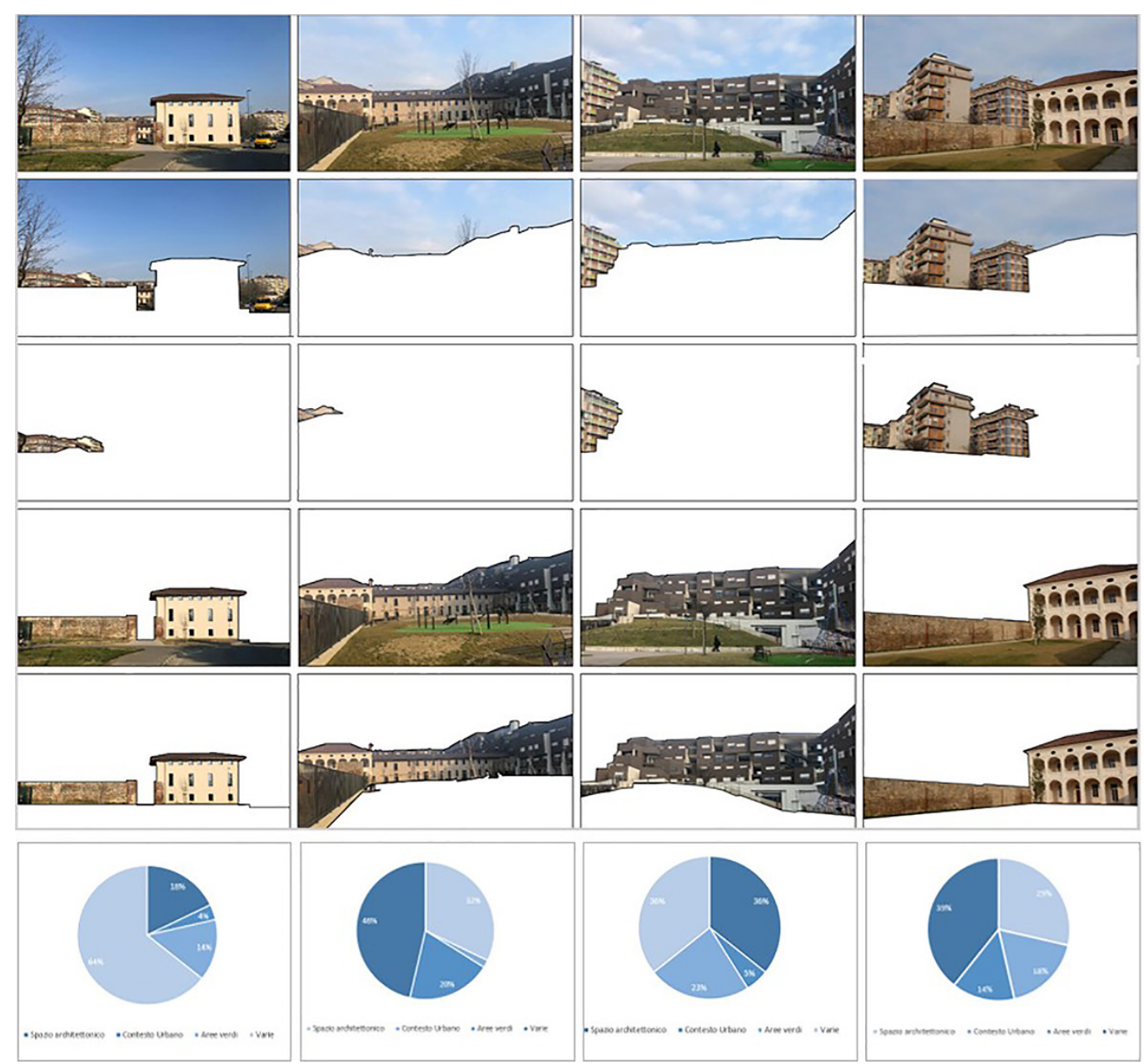
stati analizzati gli indici Spazio Architettonico e Aree Verdi e della dimensione Contesto: l'individuazione, l'evidenziazione e la quantizzazione degli elementi visibili, ci restituisce una prima rappresentazione qualitativa dell'equilibrio degli elementi all'interno del contesto urbano; partendo dalle discretizzazioni delle immagini sarà possibile ricavarne delle informazioni qualitative e quantitative (fig. 8).

I metodi di indagine hanno contemplato l'uso di diversi sistemi di rilevamento, catalogazione ed elaborazione dei dati e delle informazioni raccolte, mirati alla decostruzione della complessità indagata in entità più semplici. Si ha così la possibilità di costruire carte tematiche diverse, volte alla rappresentazione di ambiti di interesse diversi. Di seguito l'esempio di carta volta all'analisi legata all'indice dell'Accessibilità e viabilità, ovvero l'analisi alle diverse scale urbane di: Collegamento con il centro della città; Collegamento con i punti di interesse della città; Disponibilità delle strade per raggiungere altre aree della città/per uscire dalla città; Mobilità leggera | piste ciclabili; Larghezza strade; Viabilità pedonabile | dimensioni marciapiedi. Strettamente connessa all'analisi della viabilità e delle infrastrutture è l'analisi dell'indice della Fruizione, ovvero l'analisi dell'accessibilità e della vicinanza alle strutture funzionali, quali ad esempio servizi sociosanitari, aree sportive ecc... (fig. 9).

La rappresentazione dell'ambiente urbano, che in questo contesto pone l'accento sulla rigenerazione del luogo e sull'integrazione del nuovo insediamento all'interno del contesto urbano in cui è inserito, sarà la chiave di lettura delle specificità e caratteristiche degli ambienti, al fine di individuare parametri esigenziali e prestazionali caratterizzanti, che rappresentati secondo un linguaggio simbologico ad hoc, consentirà la realizzazione di tavole di sintesi del rilievo del comfort urbano e della qualità urbana percepita. (M.P.V.).

Fig. 9. Cartografia di sintesi indice di Accessibilità e viabilità e Fruizione (elaborazione a cura dell'autore).

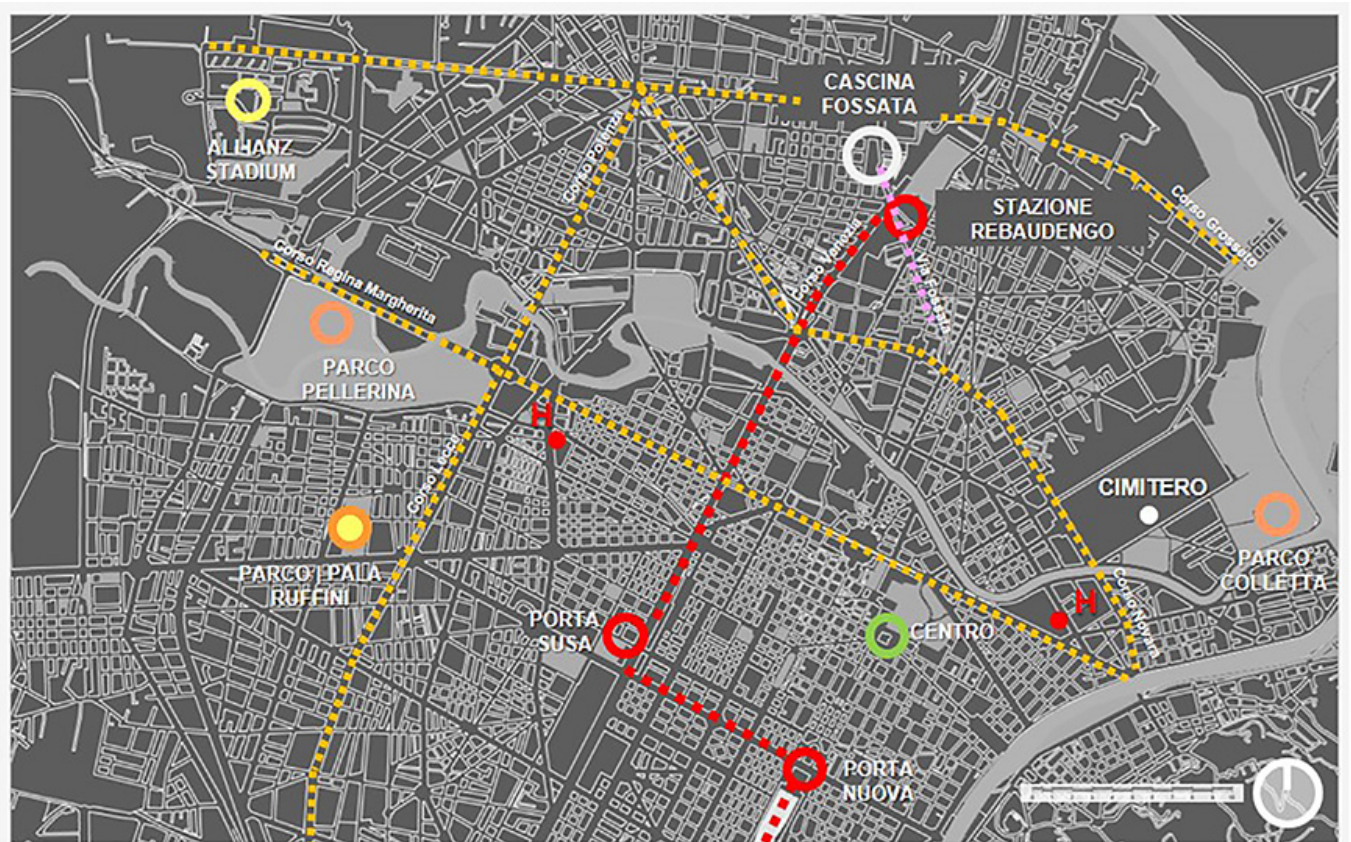

\section{Conclusioni provvisorie di una ricerca aperta}

La definizione di un metodo di indagine deve vedere integrazioni successive in termini di contenuti; questo implica un passaggio sostanziale dalla rilevazione quasi esclusivamente condotta 'a vista' (sistema analogico poi ricondotto all'insieme discreto formalizzato nelle prime versioni delle tabelle allestite nei precedenti contributi), mediata dalla sensibilità dello studioso, alla opportunità di integrare quel primo corposo insieme di dati con altri di natura 'pre-elaborata'. 
Le codifiche grafiche sopra illustrate sostengono anche loro l'impostazione metodologica; di più, consentono di estrarne gli esiti, regole applicative che ricompongono i parametri e gli indicatori individuati all'interno di una visione più ampia, che quasi pertiene alla percezione (quella sintesi mentale citata sopra), come determinanti per la definizione pluri-livello dei valori di benessere e buona vita nei luoghi. L'insieme dei dati, nella definizione passo passo del metodo, si è quindi riconfigurato fino a comprendere nature diverse di fonti. L'eterogeneità dei livelli di lettura non è stata ancora ricomposta all'interno della visione sintetica sostenuta dalla carta in quanto necessita, nella sua rielaborazione, di ambienti integrati di elaborazione (sistemi) finalizzati alla restituzione analitico-grafica dei singoli elementi.

La cucitura del vestito grafico sopra ricondotta a differenti esemplificazioni, quasi manuali, consente il tempo di maturare sulla carta, e di far quindi lì decantare, le osservazioni raccolte con le esperienze di campo (e con i cospicui archivi fotografici all'uopo allestiti, variegati e distribuiti nel tempo). Ma è l'opportunità di accedere a banche dati complesse a rendere inderogabile l'esigenza di allestire un ambiente di elaborazione che sollevi il rilevatore da tutte quelle operazioni di messa in carta (la vestizione delle planimetrie cartografiche di base). L'applicazione diffusa del metodo di rilievo e rappresentazione grafica della qualità, della sicurezza e del benessere come indicatori della resilienza urbana richiede la messa a sistema di una serie di elementi di indagine e restituzione. Se infatti, da una parte, il progressivo affinamento dei parametri da rilevare e del modo attraverso il quale questi potevano essere sinteticamente raccolti e rappresentati con 'un unico colpo d'occhio' è stato supportato da strumenti di elaborazione che oggi consideriamo di tipo 'artigianale', imbastiti caso per caso, manualmente allestiti e curati fino alla definizione dei corretti proporzionamenti tra simboli, annotazioni e segni grafici, dall'altra la necessità che si sta presentando di rendere consistenti il numero di casi studio da sottoporre a verifica e di uniformare l'impiego delle regole grafiche, richiede l'approntamento di specifici protocolli, questa volta di tipo informatico, che consentano di demandare al calcolatore gli aspetti connessi alla sintesi grafica e alla ponderazione analitica degli esiti del rilievo speditivo, anche nell'ottica di rendere accessibile e integrabile il lavoro analitico condotto (M.M.B., G.G.).

\section{Riferimenti bibliografici}

Boffi Mario (2004). Scienza dellinformazione geografica. Introduzione al GIS Bologna: Zanichelli.

Brunetta Grazia, Salata Stefano (2019). Mapping Urban Resilience for Spatial Planning-A First Attempt to Measure the Vulnerability of the System. Sustainability, I I (8), p. 233 I.

Caiffa Emanuela (20I I). ECDL GIS: La rappresentazione cartografica e i fondamenti del Gis. .......McGraw-Hill Education.

Caldera Carlo, Moglia Giuseppe (200I). Caratteri architettonici e costruttivi dei portici torinesi. In Dino Coppo, Pia Davico (a cura di). Il disegno dei portici a Torino. Architettura e immagini urbane dei percorsi coperti da Vitozzi a Piacentini. Torino: Celid, pp. 425-449.

Di Giacomo Giacomo (20 17). Un WebGis per la carta archeologica di Taormina: uno strumento per la conoscenza, la tutela e la valorizzazione. Tesi di Dottorato in Scienza Archeologiche e Storiche Antiche. Università degli Studi di Messina, XXIX ciclo.

Fornara Ferdinando, Bonaiuto Marino, Bonnes Mirilia (20 I0). Indicatori di qualità urbana residenziale percepita (IQURP). Manuale d'uso di scale psicometriche per scopi di ricerca e applicativi. Milano: Franco Angeli/Linea Test.

Garzino Giorgio (20 I0). Il rilievo del comfort degli spazi urbani: prime riflessioni per analisi speditive. In Dino Coppo, Cristina Boido (a cura di). Rilievo Urbano. Conoscenza e rappresentazione della città consolidata. Firenze: Alinea Editrice, pp......

Garzino Giorgio, Bocconcino Maurizio Marco, Donato Vincenzo (2017). Survey of Comfort and Cityscape: Methodological Considerations for the Definition of a Graphic Code and Related Experimental Applications. In Putting Tradition into Practice: Heritage, Place and Design. Milano: Springer International Publishing, pp. 537-550.

Infante Carlo (20|4). “(Ri)generazioni urbane”. In La Nuova Ecologia, maggio/20I5, pp. 48- 19.

Ingaramo Luisa (2015). Social Housing. Modelli e processi integrati per valutare la sostenibilità. Torino: CELID.

Istituto di Architettura Tecnica del Politecnico di Torino (Ricerca diretta da A. Cavallari Murat) (1968). Architettura forma urbana nella Torino barocca. Dalle premesse classiche alle conclusioni neo-classiche. Torino: U.T.E.T.

Manganaro Francesco, Arena Adrana, Altadonna Alessio (a cura di). (2018). Mario Manganaro “...un disegnatore generoso”. In memoria di M.M. Messina: EDAS sas. 
Mezzi Pietro, Pelizzaro Pietro (20 I6). La città resiliente. Strategie e azioni di resilienza urbana in Italia e nel mondo. Milano: Altra Economia.

Motta Giancarlo, Ravagnati Carlo (a cura di). (2009). Cartografia di fiume per il progetto di città. Bergamo:Tecnograph.

Piumatti Paolo, Lo Turco Massimiliano (2006). Modelli infografici per indagare e rilevare i luoghi e mercati. In Dino Coppo, Anna Osello (a cura di). Il disegno dei luoghi e mercati a Torino. Torino: Celid, pp. 21 3-229.

Samonà Giuseppe (1967). L'urbanistica e l'arvenire della città. Bari: Editori Laterza.

Spallone Roberta, Piano Andrea, Piano Simona (2016). BIM e beni architettonici: analisi e rappresentazione multiscalare e multidimensionale di un insediamento storico. II caso studio di Montemagno, Borgo Nuovo piemontese. In DisegnareCon, n. 16, pp. I- 13 .

Vozzola Mariapaola (20 I0). Un'interpretazione di sistema informativo per Piazza Carlo Emanuele II a Torino. In Dino Coppo, Cristina Boido (a cura di). Rilievo Urbano. Conoscenza e rappresentazione della città consolidata. Firenze: Alinea Editrice, pp. $195-$ 202.

\section{Autori}

Giorgio Garzino, Politecnico di Torino, giorgio.garzino@polito.it

Maurizio Marco Bocconcino, Politecnico di Torino, maurizio.bocconcino@polito.it.

Giada Mazzone, Politecnico di Torino, giada.mazzone@polito.it

Mariapaola Vozzola, Politecnico di Torino, mariapaola.vozzola@polito.it

Per citare questo capitolo: Garzino Giorgio, Bocconcino Maurizio Marco, Mazzone Giada, Vozzola Mariapaola (2020). 'Nuovi' centri urbani: metodi e strumenti grafici per la lettura della qualità e della resilienza in luoghi extra moenia con caratteri storici consolidati/'New' urban centers: graphic methods and tools for reading quality and resilience in extra moenia places with consolidated historical characteristics. In Arena A., Arena M. Brandolino R.G., Colistra D., Ginex G., Mediati D., Nucifora S., Raffa P. (a cura di). Connettere. Un disegno per annodare e tessere. Atti del $42^{\circ}$ Convegno Internazionale dei Docenti delle Discipline della Rappresentazione/Connecting. Drawing for weaving relationships. Proceedings of the 42th International Conference of Representation Disciplines Teachers. Milano: FrancoAngeli, pp. 3329-3350. 


\title{
'New' Urban Centers: Graphic Methods and Tools for Reading Quality and Resilience in Extra Moenia Places with Consolidated Historical Characteristics
}

\author{
Giorgio Garzino \\ Maurizio Marco Bocconcino \\ Giada Mazzone \\ Mariapaola Vozzola
}

Abstract

\begin{abstract}
The study presented here is part of a wider research undertaken some time ago on new themes of urban survey aimed at defining a language based on a graphic-symbolic encoding capable of describing different and heterogeneous levels of interest in the city. Through the possible declinations of the term resilience for urban contexts, the research retraces, in a sort of reasoned analysis, the cultural and disciplinary premises of urban surveying in order to reach, through successive refinements, the proposal of a system of representation. On this occasion, some methodological and applicative explorations are presented, which are the basis for further, more systematized in-depth studies. Here it is a question of introducing some basic elements to be brought within an articulated information system for the survey of quality, well-being and safety as parameters and indicators of urban resilience, also with regard to the effects of social impact, in relation to new centers for the consolidated city (historicized fabrics or object of new design). In addition to those presented on this occasion, further tests have been and will be carried out on the proposed method. This is an area of investigation that has been under investigation for some years now and is believed to have achieved a result that is for the most part reliable and stabilized, with the exception of a few unavoidable developments and maturations for experiences in the areas of the city in transformation.
\end{abstract}

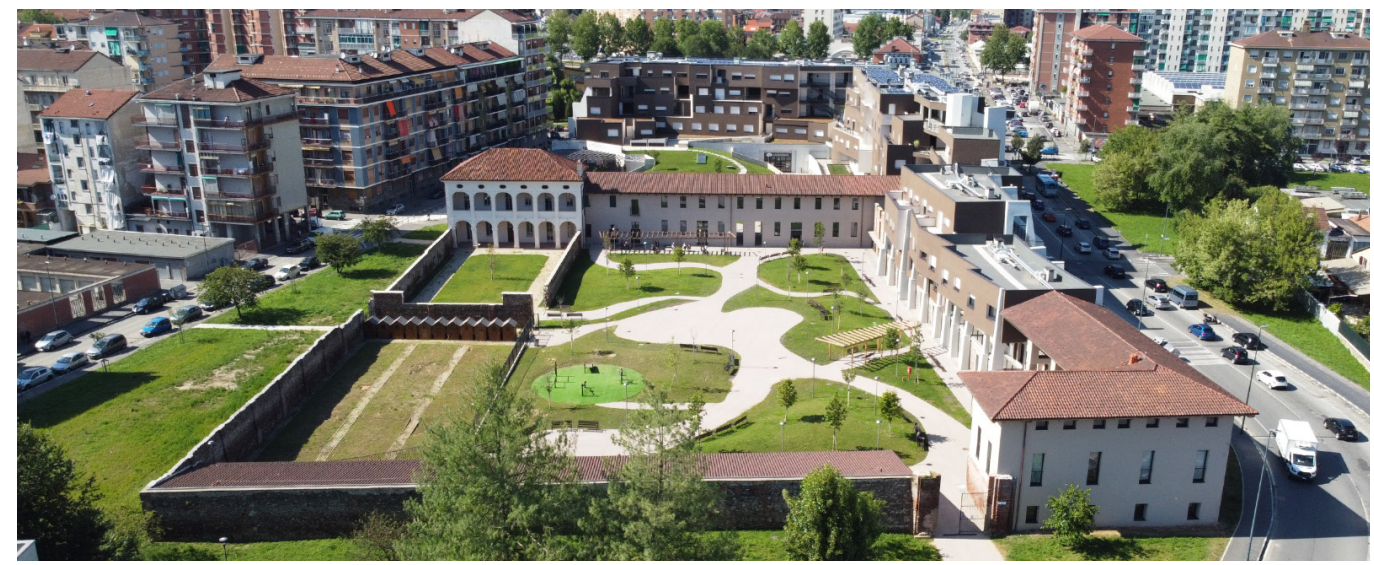




\section{Some introductory considerations}

The structure of the cartographic and figurative matrix coding that is the subject of this contribution refers to the entire body of research carried out over the last fifty years (which can be traced, albeit in updated terms, for the most part always to the cornerstones made up of Kevin Lynch's studies on the one hand and Augusto Cavallari Murat's approach on the other) and proposes methods and languages that, at least in the intentions, propose an update in the sign of methodological and scientific continuity.

Contemporaneity has by now accustomed us to the custom of communication, whatever the field to which it refers, totalizing, enveloping and immediately direct. It seemed appropriate, therefore, to put in place models of representation capable of gathering and critically collecting the knowledge acquired, proposing a reading articulated on different levels of analysis and representation.

The importance of urban quality and well-being is articulated according to the aims, therefore the expected results are different. The development of the research has among its objectives that of 'putting' the various components (detectors, scholars, designers, instruments, data and information heritage) into a system", exploiting the value of efficiency that can derive from the computer formalization of aspects related to the support of the analysis and the relative graphic-numerical result. Of this stage of deepening the operational aspects of the field, it is necessary to highlight the character of transparency, diffusion and participation as a discriminating aspect for the success of the processes of transformation and reuse of urban spaces. We hope that the drawings and illustrations proposed will become a field of comparison within which it will be possible to activate comparisons and debates; in fact, by the very nature of graphic representation it is able to highlight, through an ordered set of elements and procedures, different points of view with appropriate graphic languages. (MMB).

\section{Historical cartography for contemporary city description}

The research intends to confirm how the quality criteria of architecture, today at the basis of urban regeneration projects aimed at increasing the resilience of places, should be based primarily on the study of the geographical, territorial and urban conditions of places.

Speaking about area of interest, will be discussed not only the settlement characteristics and the relationship between architecture and place, but also the construction itself of architecture and its transformation over time, the nature and quality of which cannot be separated from them.

The central question around which this research takes its first steps, is articulated on the cognitive role that the representation has towards architecture and urban design. In addition, it focus on the possible operations that it offers as a tool capable of building and elaborating a cultural, cognitive and orienting method for who governs the transformations of cities and territory.

The importance of the work of knowledge and analysis in the processes of urban evolution is manifested starting from the birth of 'modern urban planning', as emerges from the words of Giuseppe Samonà in L'urbanistica e l'arvenire della città: "It is interesting to note that the observations of cities in constant upheaval and development, while being of a particular nature, constitute the original nucleus of increasingly extensive observations on urban phenomena, which for the first time teach us to see the city inside, in the manifold manifestations of its activity, thus creating the first context of an urban discipline gradually more aware of its tasks and functions" [Samonà 1967, p. 7].

This has contributed more and more imagining the need to order methodically, distinguish and connect, in relation to the urban character, the city various parts or to seek representation techniques capable of making visible what may not be so.

In the contemporary territory physical complexity, this way of investigating urban phenomena, which involves the construction of techniques for the recognition of the city activities 
Fig. I. Cascina La Fossata in the geographical and urban structure of Turin.

Fig. 2. Cascina La Fossata in the system of the farmhouses of the "Turin countryside". Redesign of the historical thresholds on the Carta Tecnica. Comunale.
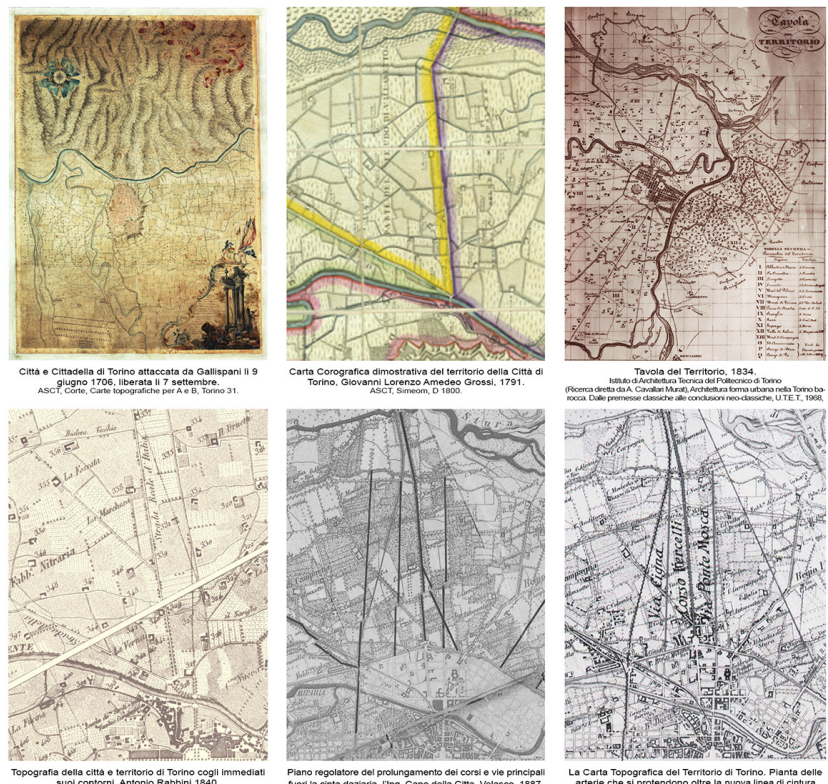

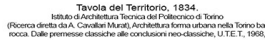
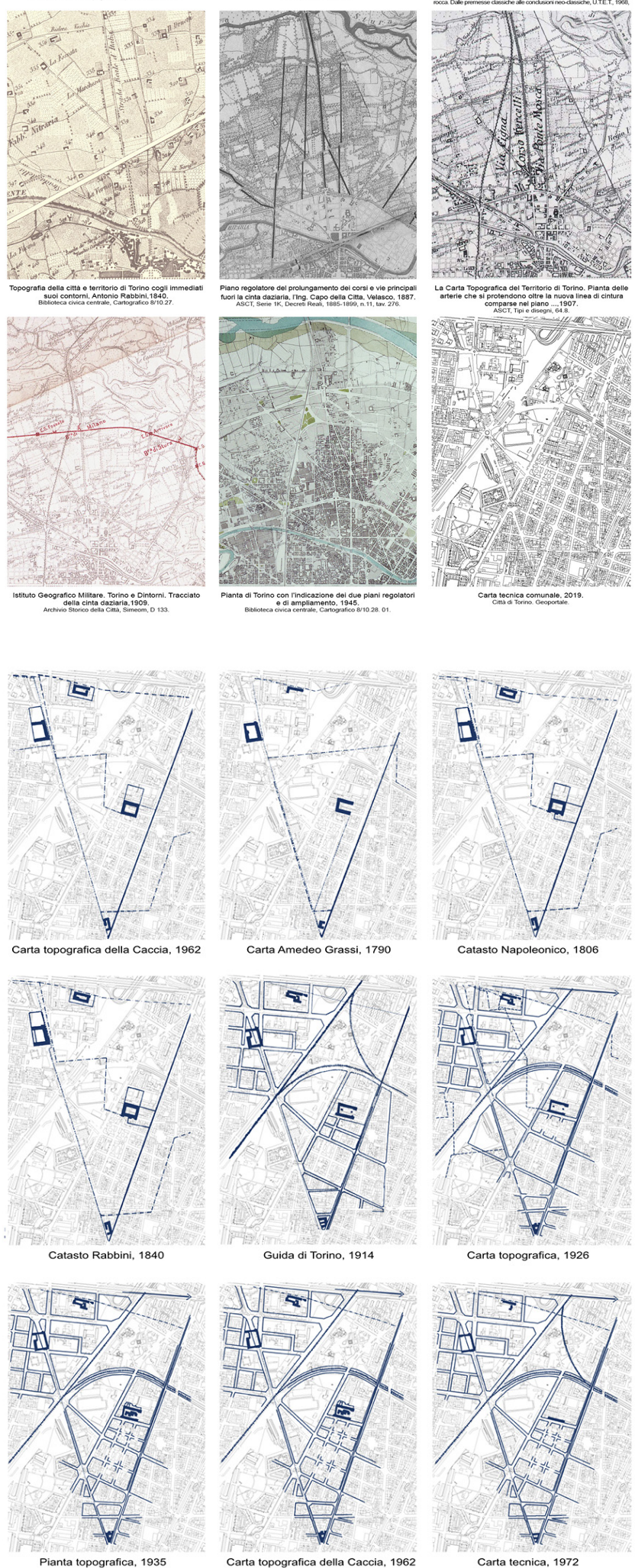
multiple manifestations, has led to studies that investigate the role played by the representation of architecture and of the city (conventional devices and diagrammatic representation), of the territory (thematic cartography), and of the social and economic aspects (signs and symbols) in the description of the places.

The city and its territory are today more and more a privileged point of reflection and investigation on the key issues running through our time and imposing themselves on our attention with the need to metabolize the past in order to become productive for the present. In urban planning, and in architecture, resilience is linked to "a particular idea of intelligence capable of remodeling itself with respect to the complexity of the events that are deconstructing cities" [Infante 20 I4, p. 49]. Urban history studies, city monographs, archaeological investigations of what remains of ancient cities, atlases that collect images of cities over time, descriptions of different types of urban formations and settlements in a region dating back to particular moments of history which have been produced with accentuated intensity since the 19th century, all these instruments allow us to trace past events and to recall their identity (figs. I-4).

On those graphic and cartographic elaborations may be based the subsequent knowledge of the formal characters of cities and territories and, from those representations, we can start experimenting with new ways of representation and converge the urban quality characters and the different results of the different disciplinary areas. They are representations of a territory that can be shared because infinite layers coexist in the cartographic space. Cartographies have the ability to represent different looks, expressions of different interests and identities thus offering through conventional signs and symbols the possibility to design the layered coexistence of the multiple categories making up the contemporary territories (fig. 5).

Fig. 3. In order: Carta della Montagna 1694-1703. Archivio Storico della Città di Torino, Pianta dei terreni di Madonna di Campagna 1683. Archivio Storico della Città di Torino, Carta Tipografica della Campagna 1685. Archivio Storico della Città di Torino, Disegno dei confini territoriali 1785. Archivio Storico della Città di Torino, Carta Corografica dimostrativa del territorio Amedeo Grossi 1791. Archivio Storico della Archivio Storico della Città di Torino, Catasto Napoleonico 1805. Ar Chivio di Stato di Torino, Catasto Gatti 1820-1830. Archivio Storico della Città di Torino, Carta Antonio Rabbini 1840 , Catasto Rabbini 1866 Archivio di Stato di Torino Pianta di Torino 1935. Archivio Storico della Città di Torino, Carta dell'Istituto Geografico Militare 1974. Archivio Storico della Città di Torino.
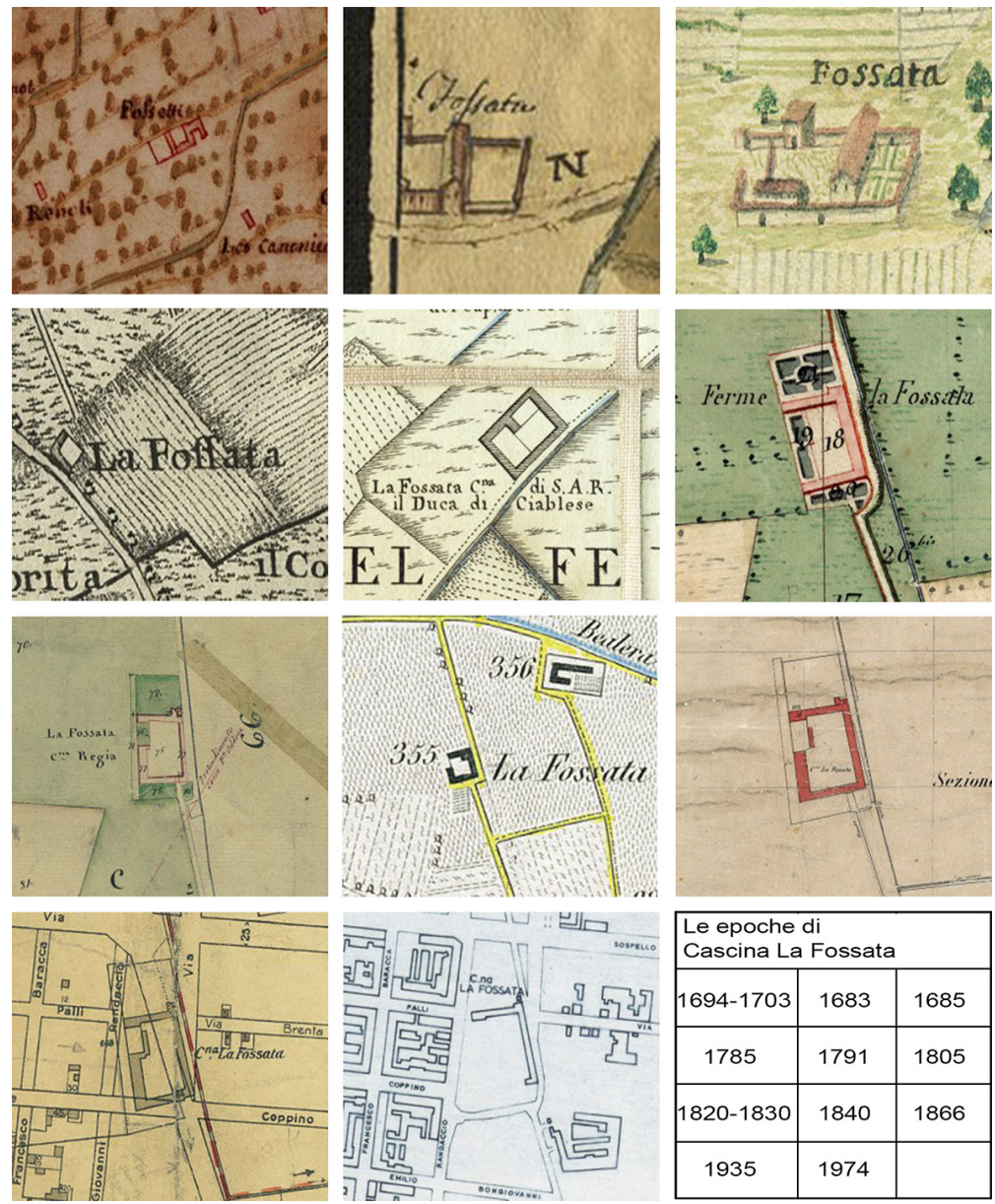
Fig. 4. Ground floor plan - Functional scheme of the Cascina La Fossata - Rilievo filologico congetturale della Cascina In: Istituto di Architetu Tecnica del Politecnico Torino deserch by A (rearari Murat). by A. Cavallari Murat), Architettura forma urbana nella Torino barocca. Dalle premesse classiche alle conclusioni neo-classiche U.T.E.T., 1968,Vol. I, II; B. fig. 27.
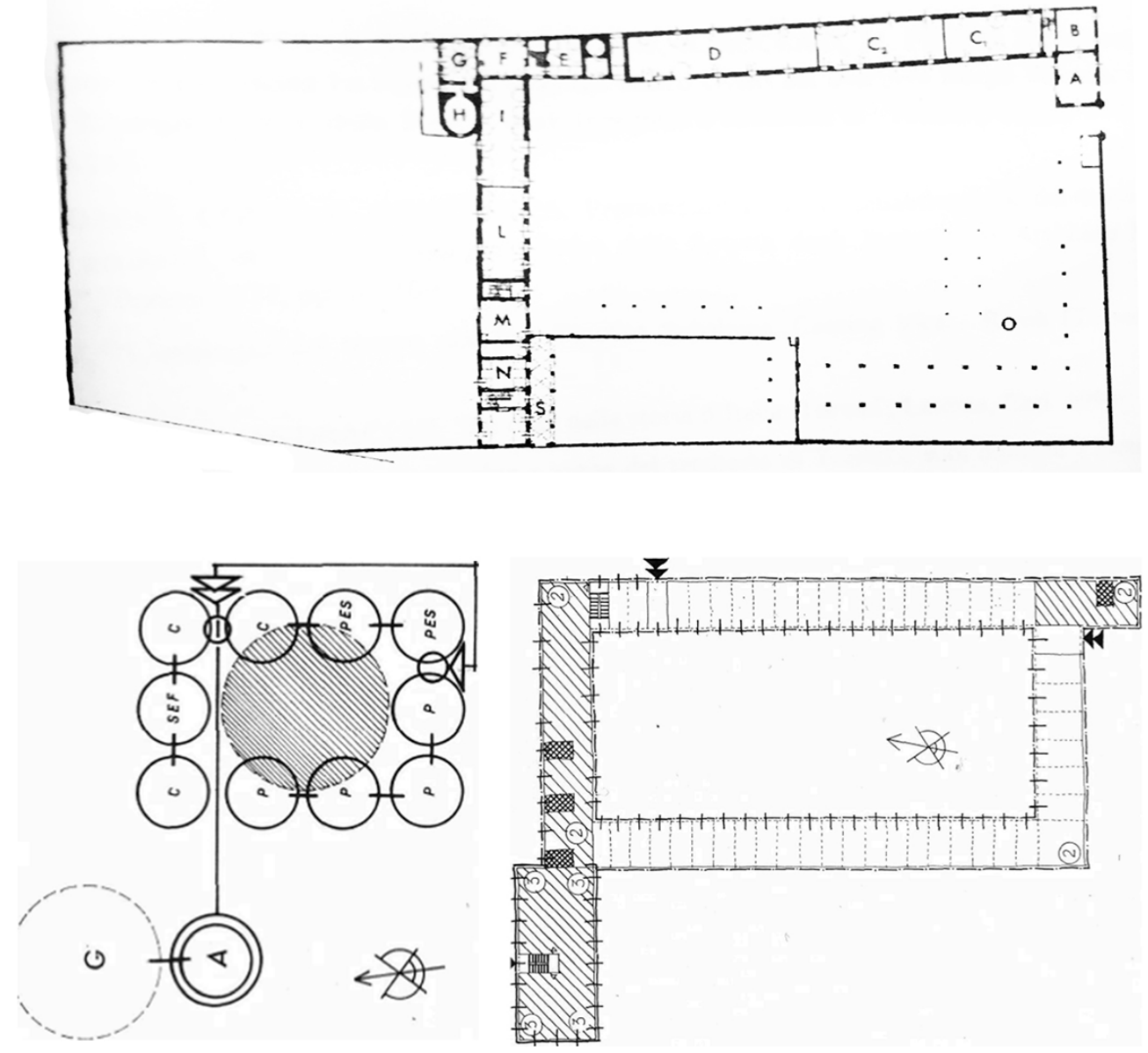

In this sense, representation allow to "trace infinite stories that dissimulate themselves in words, that generate figures, which have unfathomable semantic depths, can take the form of a thread that annotates and weaves relationships" (UID 2020) between ancient, new and renewed knowledge about the city.

Working to describe what remains of past experiences does not necessarily mean reconstructing, in the complexity of the contemporary city, through traces and signs, an image that is now irretrievably lost, but looking for a 'reconnection' of the different fragments. The representation of these fragments can, in the construction of a subtle web of relationships, work both on the physical plane and on the re-signification and re-generation of an urban space.

The in-depth analysis developed at this point of the research concerns the case of the settlement of Cascina La Fossata in Turin, of seventeenth-century origin, built north of the historic center of Turin in the agricultural territory at the time called "Turin countryside". Currently incorporated into the urban fabric following a long period of abandonment, it is the subject of a recent regeneration intervention. The Cascina example has some significant features for discussing and testing representation tools for the assessment of urban quality requirements: the relationship it has maintained, and still maintains, with the geographical characteristics of the place, the relationship it has with the logic of the settlement structure of Turin, the architectural transformations undergone in the course of history and the recent re-generation intervention; all these aspects represent the basis for next paragraph considerations. (G.M.). 
Fig. 5. Cascina La Fossata in the Turin territory, elaboration on Carta Topografica di A. Rabbini, 1840. (Antonio Rabbini, Topografia della città e Territorio di Torino. Arch vio Storico della Città di Torino).

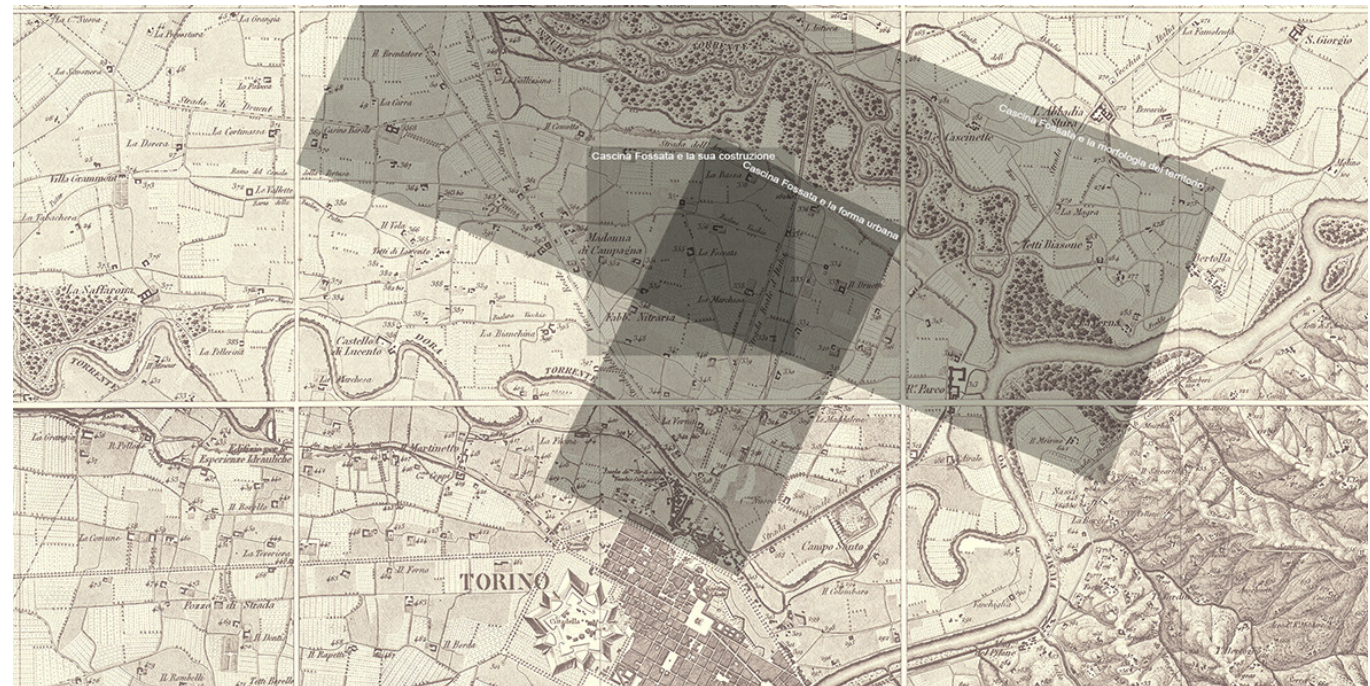

The survey and representation of urban spaces and perceived urban quality

The representation on an urban scale of the areas identified as case studies is intended as an instrument of cognitive analysis linked not only to the investigation and survey of the single architectural artefact, but as observation and study extended to a specific and characterizing urban context, as a typical fabric of the first suburbs of Turin. The research is aimed at the analysis of parameters and indicators representative of the socio-cultural evolution of the areas of interest, in order to highlight the changes in the morphology and identity of the place as a result of interventions of "requalification" and implementation of territorial services, and to evaluate, in a second phase, any improvement interventions. The survey, analysis and representation methodology, which will be used in the different research phases, takes its cue from analysis methods partly deduced from cases already developed in the literature, but nevertheless lowered and redefined in their perimeters of intervention and use, and at the same time made partly innovative with the introduction of new codes of representation, in order to meet the needs of the particular themes of study. All the data, collected and represented according to needs in different ways, will be conveyed within a multi-scale and multi-content model that can be easily read and interrogated: in this way the urban space will be investigated not only as an architectural and geometric element, but also and above all studied by enhancing 'inordinate', 'immaterial' and 'intangible' parameters that characterize the urban behavior, and focusing on the individual who lives it and the community in which it is inserted. The objective is to obtain a set of representations, exhaustive in its completeness of scale, able to harmonize and amalgamate within it the different levels of reading, but above all, able to connect data obtained from tools aimed at 'analytical' analysis of the urban and architectural context, and data obtained from 'perceptual' analysis tools, which with ad hoc measures, can transform the subjective perceptual data into analytical, in order to be able to use these parameters to compare situations before the intervention with situations after it (fig. 6).

From the surveys and analyses carried out within the study area, four dimensions of study areas have emerged, in the first instance, to which different areas of representation will be associated:

I. Visual_percettive | which includes assessments of perceived spatial density, both in the urban-architectural and human-social sense;

2. Of the fruition | inherent to the evaluation of the availability of functional structures (e.g. commercial buildings, schools, hospitals, sports centres, ...);

3. Social relationships | which focuses on population and social relations;

4. Context | which analyzes all aspects related to the urban and environmental context in which the scope of study is inserted. 
Fig. 6. Areas of study of the criteria and evaluation indices (elaboration by the author.
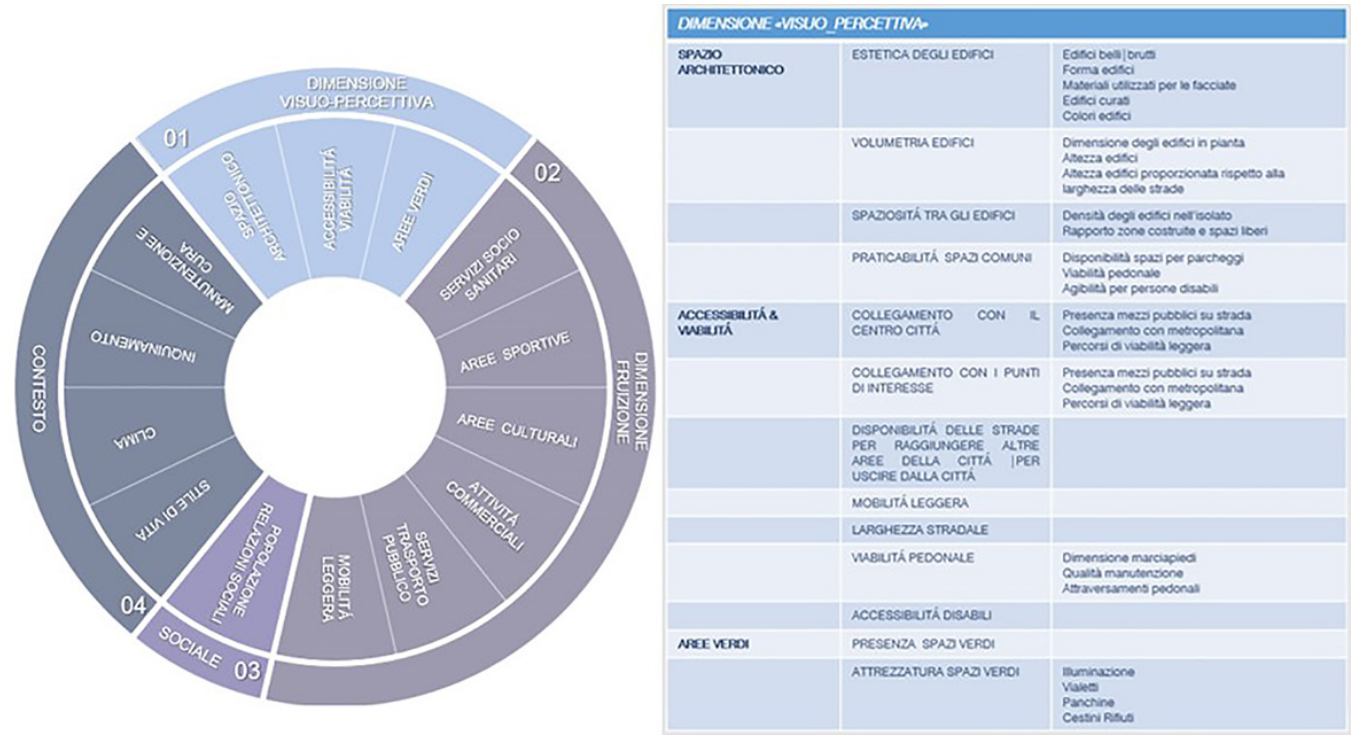

Fig. 7. Example of study sequence: from the outside to the inside of the first courtyard of Cascin Fossata (elaboration by the author).

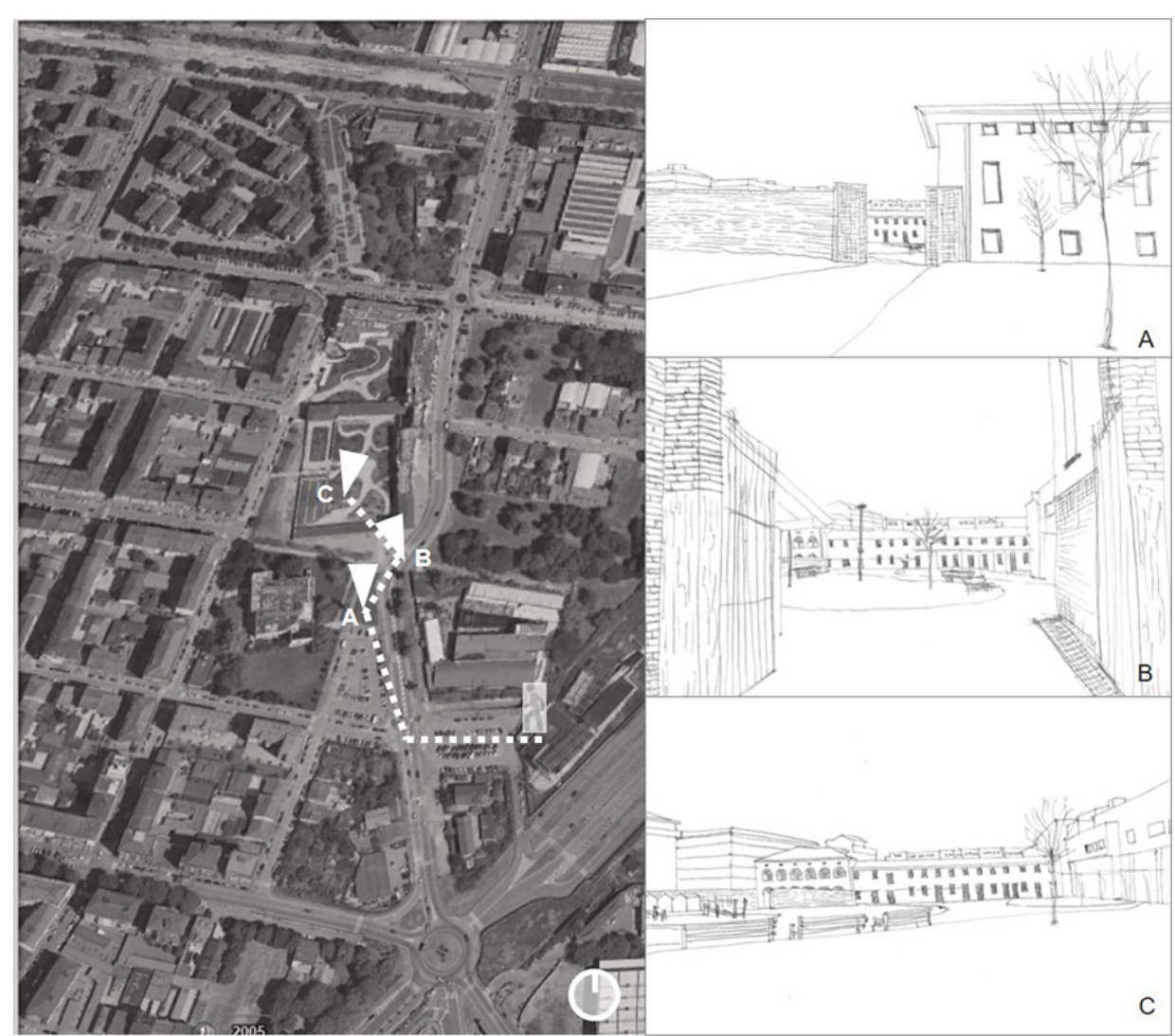


The representation and definition/description of the forma urbis, of environmental, historical and territorial resources and the analysis of their relationships, but above all the multiple information and data related to the field of investigation, from the very beginning, will take place not only through the definition of indexes, but also through the creation of images and sequential pictures, which analyze the different levels that define the environment as a whole (fig. 7)..

The images are presented as a figurative synthesis of the moments and cognitive processes conducted not only on formal and structural components and the history of urban contexts and architecture, but also on the forms and ways of life of the society that legitimized or legitimized their existence. The images of the built city are first of all made into drawings and sketches, in order to fix thoughts and emotions in front of an urban environment, and in subsequent discretized and narrated phases within qualitative and quantitative analysis sheets, thematic cartographies, two and three-dimensional representations and short films. The object of investigation is represented and interpreted through paths of approach: the use of sequences has emphasized the role of levels and projections in different versions, for this reason more images - photographic and graphic - have been reproduced that describe the same urban picture by focusing on the components that make up the scene, evaluating the incidence of the single category within the whole. The classification themes used were in a first phase those of the evaluation between private and public environment and in a second phase those of the Visual-perceptual dimension, including evaluations of perceived spatial density, both in the urban-architectural sense and in the human-social sphere, with emphasis on the architectural-urbanistic aspects. The Architectural Space and Green Areas indices and the Context dimension have been analyzed: the identification, highlighting and
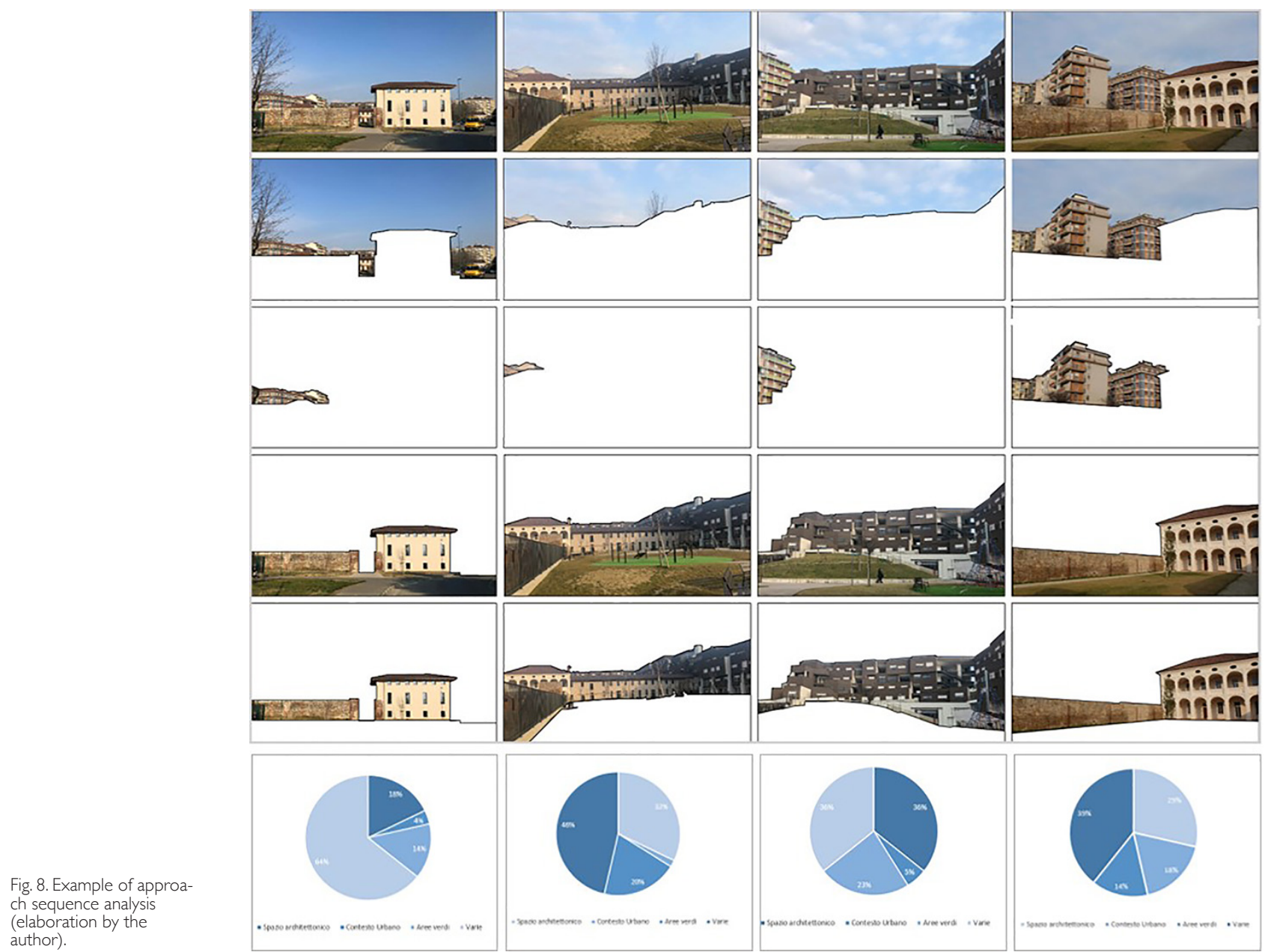
quantization of the visible elements gives us a first qualitative representation of the balance of the elements within the urban context; starting from the discretizations of the images it will be possible to obtain qualitative and quantitative information (fig. 8).

The survey methods involved the use of different systems for collecting, cataloguing and processing the collected data and information, aimed at deconstructing the investigated complexity into simpler entities. In this way it is possible to build different thematic maps, aimed at representing different areas of interest. Below is the example of a map aimed at the analysis linked to the Accessibility and Viability index, i.e. the analysis at the different urban scales of: Connection with the city centre; Connection with the points of interest of the city; Availability of roads to reach other areas of the city/to get out of the city; Light mobility | bicycle lanes; Road width; Walkways | sidewalks dimensions. Closely linked to the analysis of the road network and infrastructure is the analysis of the "Use" index, i.e. the analysis of accessibility and proximity to functional facilities, such as social and health services, sports areas, etc. (fig. 9).

The representation of the urban environment, which in this context puts the accent on the regeneration of the place and the integration of the new settlement within the urban context in which it is inserted, will be the key to interpreting the specificities and characteristics of the environments, in order to identify characteristic demanding and performance parameters, which represented according to an ad hoc symbological language, will allow the creation of summary tables of the relief of urban comfort and perceived urban quality. (M.P.V.).

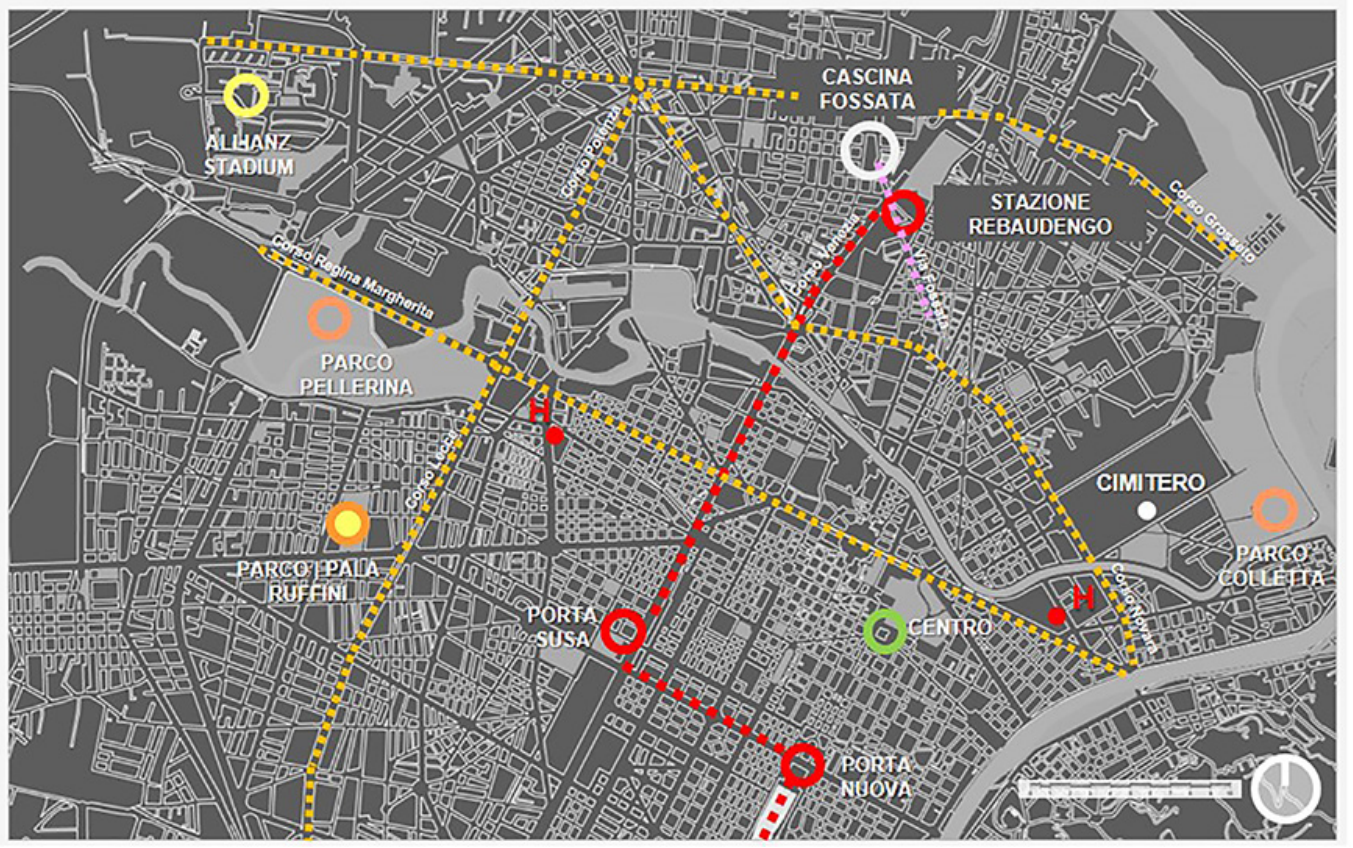

\section{Provisional conclusion of open research}

The definition of a survey method must see successive integrations in terms of content; this implies a substantial shift from the survey almost exclusively conducted 'on sight' (analogical system then brought back to the discrete set formalized in the first versions of the tables prepared in previous contributions), mediated by the sensitivity of the scholar, to the opportunity to integrate that first full-bodied set of data with others of a 'pre-processed' nature. 
The graphic encodings illustrated above also support the methodological approach; moreover, they make it possible to extract the results, application rules that recompose the parameters and indicators identified within a broader vision, which almost pertains to perception (that mental synthesis mentioned above), as determinants for the multi-level definition of the values of well-being and good life in places. The set of data, in the step-by-step definition of the method, has therefore been reconfigured to include different natures of sources. The heterogeneity of the reading levels has not yet been recomposed within the synthetic vision supported by the paper as it requires, in its reworking, integrated elaboration environments (systems) aimed at the analytical-graphic restitution of the single elements.

The stitching of the above graphic dress, which can be traced back to different, almost manual, exemplifications, allows time to mature on paper, and therefore to let the observations collected with the field experiences (and with the conspicuous photographic archives set up for this purpose, varied and distributed over time) decant there. But it is the opportunity to access complex databases that makes it imperative to set up a processing environment that relieves the detector from all those operations of putting on paper (the dressing of the basic cartographic plans). The widespread application of the method of survey and graphic representation of quality, safety and well-being as indicators of urban resilience requires the implementation of a series of survey and return elements. If, on the one hand, the progressive refinement of the parameters to be surveyed and of the way in which they could be synthetically collected and represented with 'a single glance' was supported by elaboration tools that today we consider to be of the 'artisan' type, basted case by case, manually set up and edited until the definition of the correct proportions between symbols, annotations and graphic signs, On the other hand, the need to make the number of case studies to be verified consistent and to standardize the use of graphic rules, requires the preparation of specific protocols, this time of computerized type, which allow the computer to be entrusted with the aspects related to the graphic synthesis and analytical weighting of the results of the expeditious survey, also with a view to making the analytical work carried out accessible and integrable. (M.M.B.).

\section{References}

Boffi Mario (2004). Scienza dell'informazione geografica. Introduzione al GIS Bologna: Zanichelli.

Brunetta Grazia, Salata Stefano (20 I9). Mapping Urban Resilience for Spatial Planning-A First Attempt to Measure the Vulnerability of the System. Sustainability, II (8), p. 2331.

Caiffa Emanuela (20 I I). ECDL GIS: La rappresentazione cartografica e i fondamenti del Gis........McGraw-Hill Education.

Caldera Carlo, Moglia Giuseppe (200I). Caratteri architettonici e costruttivi dei portici torinesi. In Dino Coppo, Pia Davico (a cura di). Il disegno dei portici a Torino. Architettura e immagini urbane dei percorsi coperti da Vitozzi a Piacentini. Torino: Celid, pp. $425-449$.

Di Giacomo Giacomo (2017). Un WebGis per la carta archeologica di Taormina: uno strumento per la conoscenza, la tutela e la valorizzazione. Tesi di Dottorato in Scienza Archeologiche e Storiche Antiche. Università degli Studi di Messina, XXIX ciclo.

Fornara Ferdinando, Bonaiuto Marino, Bonnes Mirilia (20 I0). Indicatori di qualità urbana residenziale percepita (IQURP). Manuale d'uso di scale psicometriche per scopi di ricerca e applicativi. Milano: Franco Angeli/Linea Test.

Garzino Giorgio (20 I0). II rilievo del comfort degli spazi urbani: prime riflessioni per analisi speditive. In Dino Coppo, Cristina Boido (a cura di). Rilievo Urbano. Conoscenza e rappresentazione della città consolidata. Firenze: Alinea Editrice, pp......

Garzino Giorgio, Bocconcino Maurizio Marco, Donato Vincenzo (2017). Survey of Comfort and Cityscape: Methodological Considerations for the Definition of a Graphic Code and Related Experimental Applications. In Putting Tradition into Practice: Heritage, Place and Design. Milano: Springer International Publishing, pp. 537-550.

Infante Carlo (2014). "(Ri)generazioni urbane”. In La Nuova Ecologia, maggio/20I5, pp. 48-19.

Ingaramo Luisa (20I5). Social Housing. Modelli e processi integrati per valutare la sostenibilità. Torino: CELID.

Istituto di Architettura Tecnica del Politecnico di Torino (Ricerca diretta da A. Cavallari Murat) (1968). Architettura forma urbana nella Torino barocca. Dalle premesse classiche alle conclusioni neo-classiche. Torino: U.T.E.T.

Manganaro Francesco, Arena Adrana, Altadonna Alessio (a cura di). (2018). Mario Manganaro “... un disegnatore generoso". In memoria di M.M. Messina: EDAS sas. 
Mezzi Pietro, Pelizzaro Pietro (20 I6). La città resiliente. Strategie e azioni di resilienza urbana in Italia e nel mondo. Milano: Altra Economia.

Motta Giancarlo, Ravagnati Carlo (a cura di). (2009). Cartografia di fiume per il progetto di città. Bergamo:Tecnograph.

Piumatti Paolo, Lo Turco Massimiliano (2006). Modelli infografici per indagare e rilevare i luoghi e mercati. In Dino Coppo, Anna Osello (a cura di). Il disegno dei luoghi e mercati a Torino. Torino: Celid, pp. 21 3-229.

Samonà Giuseppe (1967). L'urbanistica e l'arvenire della città. Bari: Editori Laterza.

Spallone Roberta, Piano Andrea, Piano Simona (2016). BIM e beni architettonici: analisi e rappresentazione multiscalare e multidimensionale di un insediamento storico. II caso studio di Montemagno, Borgo Nuovo piemontese. In DisegnareCon, n. 16, pp. I- 13 .

Vozzola Mariapaola (2010). Un'interpretazione di sistema informativo per Piazza Carlo Emanuele II a Torino. In Dino Coppo, Cristina Boido (a cura di). Rilievo Urbano. Conoscenza e rappresentazione della città consolidata. Firenze: Alinea Editrice, pp. $195-$ 202.

\section{Authors}

Giorgio Garzino, Politecnico di Torino, giorgio.garzino@polito.it

Maurizio Marco Bocconcino, Politecnico di Torino, maurizio.bocconcino@polito.it.

Giada Mazzone, Politecnico di Torino, giada.mazzone@polito.it

Mariapaola Vozzola, Politecnico di Torino, mariapaola.vozzola@polito.it

To cite this chapter. Garzino Giorgio, Bocconcino Maurizio Marco, Mazzone Giada, Vozzola Mariapaola (2020). 'Nuovi' centri urbani: metodi e strumenti grafici per la lettura della qualità e della resilienza in luoghi extra moenia con caratteri storici consolidati/'New' urban centers: graphic methods and tools for reading quality and resilience in extra moenia places with consolidated historical characteristics. In Arena A., Arena M. Brandolino R.G., Colistra D., Ginex G., Mediati D., Nucifora S., Raffa P. (a cura di). Connettere. Un disegno per annodare e tessere. Atti del $42^{\circ}$ Convegno Internazionale dei Docenti delle Discipline della Rappresentazione/Connecting. Drawing for weaving relationships. Proceedings of the 42th International Conference of Representation Disciplines Teachers. Milano: FrancoAngeli, pp. 3329-3350. 